\title{
Analysing the Prospects of Perovskite Solar Cells within the Purview of Recent Scientific Advancements
}

\author{
Aakash Bhat ${ }^{1}$, Bhanu Pratap Dhamaniya ${ }^{2}$, Priyanka Chhillar ${ }^{2}$, Tulja Bhavani Korukonda ${ }^{2}$, \\ Gaurav Rawat ${ }^{2}$ and Sandeep K. Pathak ${ }^{2, *}$ \\ 1 Department of Physics, Friedrich-Alexander-Universität, Erlangen-Nürnberg, 91054 Erlangen, Germany; \\ aakashbhat7@gmail.com \\ 2 Center for Energy Studies, Indian Institute of Technology Delhi, Delhi 110016, India; \\ pratapbhanu92@gmail.com (B.P.D.); priyankachhillar3@gmail.com (P.C.); \\ tulja.bhavani058@gmail.com (T.B.K.); gauravr343@gmail.com (G.R.) \\ * Correspondence: spathak@iitd.ac.in
}

Received: 6 April 2018; Accepted: 16 May 2018; Published: 6 June 2018

\begin{abstract}
For any given technology to be successful, its ability to compete with the other existing technologies is the key. Over the last five years, perovskite solar cells have entered the research spectrum with tremendous market prospects. These cells provide easy and low cost processability and are an efficient alternative to the existing solar cell technologies in the market. In this review article, we first go over the innovation and the scientific findings that have been going on in the field of perovskite solar cells (PSCs) and then present a short case study of perovskite solar cells based on their energy payback time. Our review aims to be comprehensive, considering the cost, the efficiency, and the stability of the PSCs. Later, we suggest areas for improvement in the field, and how the future might be shaped.
\end{abstract}

Keywords: Perovskite Solar Cells; review; solar cells; Payback time; efficiency; stability; cost analysis

\section{Introduction}

In the past few years, perovskite based solar cells have come into mainstream academic discussions, with research prospects increasing exponentially in the past three years. Perovskite was first used as an absorber for a wide spectrum of solar energy [1,2]. However, in the past few years, perovskite has been researched solely for efficiency improvements and stability issues. The power conversion efficiency has reached as high as $22.7 \%$ [3] which makes it a legitimate competitor for other cells such as polycrystalline silicon solar cells. Scientists have begun using perovskites for tandem solar cell applications, which would further increase the efficiency of solar cells to 25-30\% [4]. For instance,

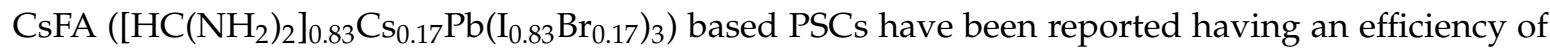
23.6\% when placed on top of infrared-tuned silicon heterojunction bottom cell.

Recently, crystalline silicon heterojunction solar cells have achieved a PCE greater than 25\% [5] when an interdigitated back contact structure was used to reduce optical loss. A heterojunction between amorphous silicon and crystalline silicon, with intrinsic thin layer solar cell has shown an efficiency of $24.7 \%$ with a cell thickness of $98 \mu \mathrm{m}$ [6]. Meanwhile, black silicon solar cell has been a breakthrough in the field of efficient and stable solar cells with an efficiency of $22.1 \%$ attributed to interdigitated back contacts [7] and wide absorption in solar spectrum. On the other hand, new technologies such as IBSC (Intermediate Band Solar Cells), organic solar cells, and low cost CdTe solar cells have also boomed, which require intense research before being commercialised. 
Organic-inorganic hybrid perovskite has a high absorption coefficient $\left(\sim 10^{5} \mathrm{~cm}^{-1}\right)$ [8], wide range absorption in solar spectrum (300-900 nm) [9], low excitonic binding energy (19-50 meV) [10], long electron/hole diffusion length (100-1000 nm) [11], and a tuneable band gap [12]. Because of these properties it has attracted considerable attention nowadays.

Unlike most conventional technologies, the biggest problem faced by perovskite solar cells is stability in the operating environment. However, its low-cost fabrication advantage has driven the research so far despite the competitive market. The fabrication methods involve solution processable techniques such as spin-coating and dip coating. There exist other approaches such as chemical vapour deposition (CVD) [13], atomic layer deposition (ALD) [14], plasma enhanced CVD (PECVD) [15], etc., which are costlier compared to solution processable methods.

In this article, we first go over studies on efficiency of PSCs. After that, we discuss other aspects of perovskite solar cells which are being researched: stability, cost, and energy payback time. We also discuss tandem solar cells and later, the future of perovskites as energy solutions at low cost.

\section{Discussion}

Within the context of this paper, it is important to first define the relationship between efficiency, stability, and cost, and the overall effect of the three on any solar cell technology. The most basic view that is be sufficient for now can be summarized as follows:

A solar cell, essentially, is made of a light absorbing material sandwiched between charge extraction layers and connected to electrodes. While identifying an effective absorber material which can harvest a significant portion of visible spectrum plays a crucial role in photo-charge generation, the electron and hole transport layers (ETL and HTL, respectively) aid the charge transport and collection. Quantizing the quality of the solar cell can be effectively done by efficiency measurements. However, commercialization demands a trade-off between efficiency and the production cost. In the case of PSCs, although the efficiencies were not comparable to Si-solar cells during the early days, economic lab scale processing and cheap material inventory lead to intensified research. Although the efficiencies leapt to new heights in less than a decade, PSCs constantly suffered in stability and reproducibility. Perovskite is highly sensitive to environment unlike conventional absorber materials and requires extra efforts to achieve a stable performing cell. Thereby the research groups strive to address the trio: (1) cost effectiveness; (2) high efficiency; and (3) outdoor/field stability. It is implicit that the three are interlinked; the key to commercialization is to positively tweak the balance between this trio as much as possible.

Furthermore, research in PSCs involves the optimization of the three issues stated above, whereas work on established Si-cells is often carried out to reduce the production cost. With an aim to resolve the vague idea about the efficiency of the PSC, we first tried to define the theoretical limitations on efficiency.

\section{Theoretical Limitations in the Performance of Perovskite Solar Cell}

When there are a high number of research groups involved in efforts of increasing the power conversion efficiency of perovskite solar cells, it is important to know the maximum amount of photon energy conversion that can be attained. Earlier, in 1961, Shockley and Queisser proposed a detailed balanced limit method for a single junction single absorber layer, which gave an idea of limiting values. However, this theoretical efficiency limit is restricted by several parameters and takes only the ideal cases into consideration such as: photo recycling and pondering upon the optical band gap of the absorber having only radiative recombination $[16,17]$ (in the theoretical limit). Hence, the necessity arises to determine the practical limit for the efficiency along with the basic facts mentioned in the S-Q model [16].

Pabitra et al. (2014) [18] made a realistic approach to explain the limit of perovskite solar cell technology in terms of basic cell parameters such as short circuit current, open circuit voltage, fill factor, etc. Their calculations demonstrated that the ratio of maximum Jsc attained until date by 
a laboratory cell to the maximum theoretical current was $79 \%$ for mixed halide case and $71 \%$ for iodide-based perovskite. One can infer from it that there is a possibility of improvement in the Jsc. Similar calculations were made for Voc values and reported overpotential was $0.73 \mathrm{eV}$ for mixed halide perovskites. The reason for this might be the losses at the interfaces.

Seki et al. reported that the maximum PCE that can be achieved in perovskite solar cell is $26-27 \%$, which can be obtained at an optical band gap of around $1.4 \mathrm{eV}$ and considering the voltage loss of $0.2 \mathrm{eV}$ between $\mathrm{TiO}_{2}$ and $\mathrm{CH}_{3} \mathrm{NH}_{3} \mathrm{PbI}_{3}$ layer. They calculated that, if the voltage loss can be reduced to $0.1 \mathrm{eV}$, then efficiency limit can be extended to $30 \%$ [19]. Later, another study conducted by Oscar et al. calculated the efficiency limit as $25-27 \%$. In the observations, they mentioned that intrinsic properties of the material are not the limiting factor of conversion efficiency, but the proper alignment of ETL and HTL are [20]. Recently, Wei et al. reported that the maximum limit for conversion efficiency is $31 \%$. They have also certified that the efficiency limit of perovskite can be improved with light trapping through $h$ texturing [21].

With the studies performed on the maximum efficiency limit, it is clear, that there is much more scope for performance improvement. Numerous researchers have investigated the field which will be expounded in the next section.

\section{Scientific Progress Made So Far in Perovskite Solar Cell}

\subsection{Photo Conversion Efficiency}

As discussed earlier, PSCs are proven to be low cost solar cells with easy and flexible fabrication technologies.

Edward J. W. Crossland et al. [22] in 2013 showed that mesoporous single crystals compiled with perovskite sensitizer layer delivered higher efficiencies than normal solar cells at low temperatures. Since then, there has been a race for the highest efficiency. The efficiency limit of PSC has been predicted to be about 31\% [17], nearly reaching the Shockley-Queisser limit of 33\%, according to the detailed balance method [23].

The performance of Perovskite solar cells depends on many factors, including the restrictions of stability and cost. For example, Mesoporous $\mathrm{TiO}_{2}$ usage has shown the highest efficiency but it requires a temperature of $450{ }^{\circ} \mathrm{C}$ to be fabricated. On the other hand, planar heterojunction cells are simpler but have hysteresis losses in efficiency. Although devices with efficiencies more than $20 \%$ have been fabricated, the limit can be overstepped by focussing on the imperfections involved in the fabrication process of the cell. The major research is centred on different components of the perovskite solar cell which can be tweaked to achieve better results. Therefore, the discussion on efficiency can be divided into the following basic areas according to their functioning.

\subsubsection{Improvement in Perovskite Film Quality}

A good quality absorber layer is the foremost requirement to attain highly efficient devices. Perovskite film fabrication method generally involves solution processable techniques such as one step deposition, sequential deposition method, etc. The polycrystalline perovskite absorber developed via these techniques is generally associated with incomplete film coverage and defect sites at grain boundaries. These crystallographic imperfections and charge trap centres favour non-radiative recombination and hence deteriorate the electrical output of the device. Various research groups have facilitated numerous techniques to improve the film quality by means of improving the microstructures and passivating the defect states. A few of them are covered in this section.

\section{Improvement in Microstructure}

Film morphology of the substrate is highly dependent on the precursor used in the fabrication of the film. Snaith's group in their article made a comparison in the perovskite film quality fabricated when taking $\mathrm{PbCl}_{2}, \mathrm{PbI}_{2}$, and $\mathrm{Pb}(\mathrm{Ac})_{2}$ as the lead sources in the precursor. They observed that the 
film prepared from $\mathrm{Pb}(\mathrm{Ac})_{2}$ precursor have smaller grains but dense and uniform film as compared to the film made from $\mathrm{PbCl}_{2}$ and $\mathrm{PbI}_{2}$ sources. However, $\mathrm{PbCl}_{2}$ based film give larger grains with less number of nucleation sites but the film quality is not up to the mark due to incomplete coverage. Another advantage mentioned is the shorter annealing time required for crystallization of the $\mathrm{Pb}(\mathrm{Ac})_{2}$ based film when compared to the others. Overall, they concluded that using $\mathrm{Pb}(\mathrm{Ac})_{2}$ in the precursor gives faster crystallization with smooth film and relatively better surface coverage along with low energy requirements [24]. In the sequence of achieving uniform perovskite film, Nie et al. (2015) [25] tried coating the perovskite film on hot substrate with pre-heated precursor solution. They analysed that increasing the substrate temperature $(>130)$ leads to larger grains. With substrate temperature of $190{ }^{\circ} \mathrm{C}$, grain size up to $1 \mathrm{~mm}$ was achieved. When the substrate is heated at temperatures above the perovskite crystallisation temperature, there is sufficient amount of solvent available and it will reduce the number of crystallisation sites, resulting in bigger grains. With the method reported, they were able to produce a device with $18 \%$ PCE efficiency.

Saliba et al. [26] incorporated $\mathrm{Rb}$ cation in the perovskite which helps in stabilizing the black phase of perovskite. The addition of this cation supports the crystallization of photoactive phase giving sharp PL emission. With the RbCsFAMA based perovskite device, they got the best cell efficiency of $21.6 \%$.

Yun et al. in 2017 demonstrated a new method to improve the perovskite film morphology. The added $\mathrm{NiO}$ nanotubes in the precursor solution of perovskite to support large grain formation by acting as a framework at the time of annealing. With this the film obtained had bigger grains (average size $1100 \mathrm{~nm}$ ) as compared to controlled film $(700 \mathrm{~nm})$. The best efficiency achieved by this modification was 19.3\% for planer devices [27]. In the research work conducted by Yongzhen et al. using ionic liquids and molecular additives such as methylammonium acetate and thiosemicarbazide respectively in the precursor solution enhanced the film quality, providing smooth dense and larger grain films. With this chemical engineering, a PCE of around 19\% was achieved with the advantage of improved stability. They noted that the device showed an improved stability by retaining $80 \%$ of its initial efficiency after $500 \mathrm{~h}$ while subjected to a temperature of $85^{\circ} \mathrm{C}$ [28].

Yang Bai et al. used a crosslink structure of C60-SAM and silane. The modification provides a surface passivation giving high efficiency of around $19 \%$, as well as the hydrophobic $\mathrm{CF}_{3}$ group in the material improves the stability by retaining $90 \%$ of the initial PCE even after 30 days of ambient exposure [29].

Zhou et al. (2014) reported that a better morphology can be achieved using controlled humidity environment. At the same time, they used Y-doped $\mathrm{TiO}_{2}$ as the ETL for increased conductivity. Overall modifications result in the device efficiency of 19.3\% for the champion cell [30].

Yang et al. (2016) reported an Ostwald ripening phenomenon in $\mathrm{CH}_{3} \mathrm{NH}_{3} \mathrm{PbI}_{3}$ films when treated with $\mathrm{MABr}$ in IPA solution. With the optimum concentration of $\mathrm{MABr}(2 \mathrm{mg} / \mathrm{mL})$, compact film with larger grains was fabricated which leads to stabilised PCE of around 19\% [31]. Similar kind of MABr surface treatment was also employed by Han et al. with $2 \%$ absolute improvement in the PCE. Similarly, Jose at al. reported $\mathrm{MACl}$ treatment to enhance the optoelectronic properties of controlled perovskite film [32]. Bert et al. treated perovskite layer with MA and got smooth pin hole free compact layer which improved the photo-physical properties and hence the performance [33].

Additives in precursor: Liu et al. (2017) added $\mathrm{V}_{2} \mathrm{O}_{x}$ solution in the precursor which helped in obtaining the large perovskite grains. Existence of $\mathrm{V}_{2} \mathrm{O}_{\mathrm{x}}$ in the precursor forms hydrogen bonding with the $\mathrm{CH}_{3} \mathrm{NH}_{3} \mathrm{PbI}_{x} \mathrm{Cl}_{3-x}$ which helps at the time of crystal growth. With $2.5 \mathrm{wt} \%$ of $\mathrm{V}_{2} \mathrm{O}_{x}$, they achieved an efficiency of $16.14 \%$. In addition, the additive helps in retaining $70 \%$ of its initial efficiency after $1000 \mathrm{~h}$ of air exposure [34].

In the two-step method, Wu and co-workers (2017) added DMF in the FA/MA/IPA solution and found better perovskite conversion with improved optical properties and less defect centres. Steady state power output of $20.1 \%$ was achieved with $2 \%$ DMF content [35]. 
Zhang et al. (2018) reported that adding 1 vol \% graphene oxide in the perovskite precursor solution improves the grain size from $100 \mathrm{~nm}$ (for pristine film) to $200 \mathrm{~nm}$. With the improved quality they achieved a PCE of $17.59 \%$ [36]. Similarly, Faraji et al. have used benzoquinone (BQ) as additive to get the higher efficiency [37]. Xie et al. have reported cyclic urea as additive in the precursor solution for better performance [38].

Wang et al. demonstrated vapour deposition solution hybrid method (VSHM) to achieve smooth and pin hole free perovskite film. In the method reported, they developed $\mathrm{CH}_{3} \mathrm{NH}_{3} \mathrm{PbI}_{3}$ perovskite film by solution deposition method, after which they have fabricated another layer of perovskite by vacuum deposition. The vacuum deposited perovskite layer followed a two-step approach fabricating $\mathrm{PbCl}_{2}$ layer followed by MAI deposition [39].

\section{Reduction in Non-Radiative Losses}

Defect sites arise in the perovskite layer at the time of fabrication and are the major cause of non-radiative recombination. These trap sites reduce the optoelectronic properties of perovskite layer thereby lowering the device efficiency. Several groups have tried to reduce these losses in the absorber material by employing various modifications/passivation to the perovskite layer. Zhang et al. used hypo-phosphorous acid (HPA) in the perovskite precursor solution which improved its morphology by helping in the formation of large diffused grains. The addition of HPA also reduces the possibilities of iodine oxidation at the time of crystallization of the film, thus lowering the bulk defects [40]. Yang et al. reported a new mechanism to stabilize the iodine deficiencies in the perovskite layer. In the two-step approach of perovskite formation, they used an iodide ion rich solution in the deposition of the second step. This iodide ion-based solution was prepared by dissolving solid iodine at $80^{\circ} \mathrm{C}$ in isopropyl alcohol. With this defect engineering, they achieved a PSC device with a certified efficiency of $22.1 \%$ [1].

Henry's group in 2014 reported treatment of perovskite surface with Lewis bases such as pyridine and thiophene. The treatment resulted in the passivation of unsaturated $\mathrm{Pb}$-bonds available on the surface of the perovskite and lead to increased luminescence and efficiency [41].

Non-radiative losses arising in the perovskite film can also be a cause of strain in the crystal. Wang. et al. employed $\mathrm{Al}^{3+}$ doping in the perovskite by supplementing $\mathrm{Al}$-actylacetonate in the precursor solution. A trade off in the optoelectronic properties of the perovskite has been observed by tuning the concentration of the dopant material. They concluded that adding $0.15 \mathrm{~mol} \%$ of $\mathrm{Al}$ dopant can lower the strain in the film, eventually minimizing the electronic disorders. With 0.15 mol \% doping, they achieved a PCE of $19.1 \%$ with the additional benefit of negligible hysteresis [42]. Doping of alkali metal such as $\mathrm{Na}^{+}$and $\mathrm{K}^{+}$was also reported by Wangen et al. (2018) to improve the surface smoothness and to reduce the defects sites at grain boundaries [43]. The inherent property of these cations is that they cannot be oxidised or reduced, therefore making them appropriate for the purpose. Zhao et al. were able to passivate the grain boundary defects states by treatment of diammonium iodine $\mathrm{C} 8$ without altering the $3 \mathrm{D}$ structure of the perovskite. $\mathrm{C} 8$ treatment lead to filling the spaces between the grain boundaries and reduced the roughness of the film, consequently improving the electronic quality of the active layer [44].

Ming et al. processed the perovskite surface with small molecules (named as boron subphthalocyanine chloride (SubPc)) solution. The molecules of SubPc intrude in the grain boundary regions and suppress the trap states associated with the grain boundaries leading to enhanced device performance [45]. Jamaludin et al. incorporated tetraethylammonium bromide cation on the surface of the perovskite for the defect state passivation [46]. Jiang and co-workers introduced a polymeric 2D material g- $\mathrm{C}_{3} \mathrm{~N}_{4}$ in the precursor solution of the $\mathrm{CH}_{3} \mathrm{NH}_{3} \mathrm{PbI}_{3}$. At the time of film fabrication, these $\mathrm{g}-\mathrm{C}_{3} \mathrm{~N}_{4}$ molecules slow down the crystallisation process of perovskite and reduce the possibility of charge recombination at interfaces. With the modification, a notable efficiency of $19.49 \%$ was acquired [47]. 


\subsubsection{Improvement in Hole Collection Efficiency}

Spiro-OMeTAD remains the most widely used hole transporting layer in PSCs, and the material with which other HTMs are compared. Its usage however precedes perovskite as it has previously been used as an HTL in dye sensitized solar cells [48]. Nam Joong Jeon et al. [49] studied three Spiro-OMeTAD derivatives and observed the optical and electronic properties by changing the positions of the two methoxy substituents in each quadrant. The cell performance was found to be dependent upon the position of the methoxy groups with o-OMe substituents showing the highest efficiency of $16.7 \%$. In a similar manner, Dong Shi et al. [50] grew single crystals of Spiro-OMeTAD and determined its crystal structure, appearing contrary to what was previously known, finding that Spiro-OMeTAD's single-crystal structure has a hole mobility that is three orders of magnitude greater than that of its thin-film counterpart. They used methanol as an anti-solvent to crystallise the Spiro-OMeTAD crystals showing further optimization in the same direction that could help in boosting the solar cell efficiency.

Nazeeruddin and group invented a new method to passivate the defects on the perovskite surface at HTM side. They introduced a thin layer of another perovskite $\mathrm{FAPbBr}_{3-\mathrm{x}} \mathrm{I}_{\mathrm{x}}$ between existing perovskite and hole transporting material. This passivation was achieved by spin casting FABr on the primary layer. It was expected that the unreacted $\mathrm{PbI}_{2}$ in the primary layer may react with the FABr and form another perovskite, as stated earlier. With the XRD pattern, they proved that the partially reacted $\mathrm{PbI}_{2}$ was converted into perovskite, suppressing the defects and enhancing the Voc. This modification resulted in an efficiency of $21.3 \%$ for the best cell [51].

Recently, Jae Choul Yu and co-workers reported 18\% efficient perovskite devices in the inverted architecture using PEDOT:GO as the hole transport layer. This increased device performance can be attributed to superior morphology of the film with reduced contact potential between HTL/perovskite. Use of this PEDOT and GO composite instead of conventional PEDOT:PSS film improves the hysteresis loss in the device [52].

$\mathrm{NiO}_{\mathrm{x}}$ has emerged as a new HTL material due to its advantages such as robustness to the environment and preferable energy level alignments. Seongrok et al. used $\mathrm{NiO}_{\mathrm{x}}$ based $\mathrm{HTL}$ in their inverted perovskite architecture which exhibited an efficiency of 16.4\% [53]. Park et al. also fabricated $\mathrm{NiO}_{x}$ as HTL layer by electrochemical method and reported a power conversion efficiency of $17 \%$ for $1 \mathrm{~cm}^{2}$ area devices [54]. Furthermore, many groups have suggested doping of a transition metal in $\mathrm{NiO}_{\mathrm{x}}$ to enhance the electrical properties and morphology of the layer. Recently, Wei Chen et al. reported Cs-doping in $\mathrm{NiO}_{x}$ layers in inverted perovskites which facilitates deep valence band leading to an efficiency gain of $19.35 \%$ [55]. Similarly, doping of $\mathrm{Co}, \mathrm{Li}-\mathrm{Cu}, \mathrm{Cu}$, and $\mathrm{Ag}$ have also been reported [56-59].

A small subset of improving the hole transport layer is changing the layer itself, which often allows for an inverted structure of the perovskite to be used.

Dewei Zhao et al. in 2014 studied the inverse perovskite solar cell architecture, placing the hole transport layer on the transparent electrode. Because of problems with PEDOT:PSS in the inverted case, the researchers chose poly[ $N, N^{\prime}$-bis(4-butylphenyl)- $N, N^{\prime}$-bis(phenyl)benzidine] (poly-TPD) as the hole transport layer and electron block layer. The device showed an efficiency of $13.8 \%$ on an average with a maximum of $15.3 \%$. Poly TPD devices performed much better than PEDOT:PSS based devices owing to large crystallites in the former case [60].

Another case of a Spiro-structured HTM is the spiro[fluorene-9, $9^{\prime}$-xanthene] (SFX) based HTM-X60 (Figure 1) which has been shown to give an efficiency of $19.84 \%$. X60 is comparatively easily synthesizable and therefore might be a promising candidate for large-scale industrial production [61]. Knowing that Spiro-OMeTAD is expensive, there are other materials which have been studied for HTM purposes. However, none of them is probably as well known as H101 based on 3,4-ethylenedioxythiopene (Figure 2). H101 is the first heterocycle containing material which achieved an efficiency greater than $10 \%$, therefore being comparable to Spiro-OMeTAD. Additionally, it is also cheaper and easier to synthesise [62]. 


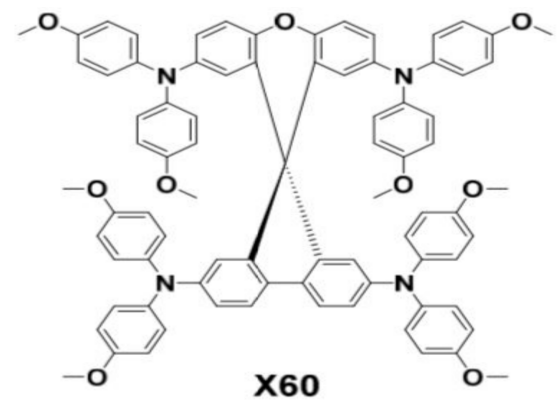

Figure 1. The structure of X60 as used by Xu et al. [61].

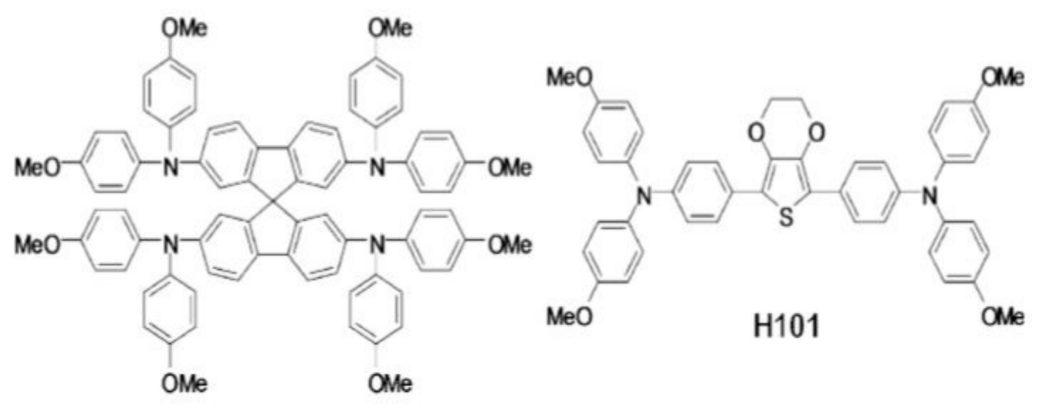

Spiro-OMeTAD

Figure 2. Spiro-OMeTAD and H101 structure comparison; H101 being easier to synthesise. (from Li et al. [62]).

Triazatruxene-based Hole transporting materials with 18.3\% PCE [63], PTAA with max PCE of 12\% [64], poly (3,4-ethylenedioxythiopene) PEDOT with 17\% PCE [65], Spiro-Phenylpyrazole/Fluorine with 14.2\% [66], conjugated polyelectrolytes with 12\%+ [67], and MEH-PPV and P3HT with 9.65\% [68] are other hole-transporting materials which have been successfully investigated.

\subsubsection{Improvement in the Electron Collection Efficiency}

Efficiency of the overall device is greatly dependent on how well we can extract the photo-induced charges generated in the absorber layer. Inefficient transport of charges from perovskite to electrodes results in the dropdown of power conversion efficiencies. The term "inefficient charge transport" refers to recombination losses at the interface due to existence of trap states and losses due to defects in the charge collecting material itself. For collection of electrons a commonly reported ETL is c- $\mathrm{TiO}_{2}$ or mesoporous $\mathrm{TiO}_{2}$. This material is associated with the surface defects generated from the oxygen vacancies in the near conduction band region due to unsaturated Ti(IV) valancies. At the time of charge transfer from absorber layer to ETL, there is a high probability that the electron can be trapped through the oxygen vacancies at the interface and lead to non-radiative recombination losses.

Three basic ways can be identified to mitigate the recombination losses in the charge transport from perovskite to ETL.

Overcoming the Defects Present in the Material Itself

Doping in $\mathrm{TiO}_{2}$ has been proven as an effective way to reduce the defect densities. In 2014, Pathak et al. reported $\mathrm{Al}$ doping $\mathrm{TiO}_{2}$ for reducing the deep sub band gap trap sites in $\mathrm{TiO}_{2}$ for efficient charge collection in DSSC and perovskite solar cells [69]. Later, Chen et al. reported that $\mathrm{Nb}$ doped $\mathrm{TiO}_{2}$ improves the PCE of perovskite by improving the carrier density and electron injection probability [70]. Michael Graetzel's group in 2016 reported an improved PCE of 19\% with Li doped $\mathrm{TiO}_{2}$ [71]. Jun et al. [72] and Xiangling et al. [73] also analysed the effect of Indium and $\mathrm{Fe}^{3+}$ doping 
in $\mathrm{TiO}_{2}$, respectively, and found that the device performance was upgraded as compared to that of pristine $\mathrm{TiO}_{2}$. Doping in $\mathrm{TiO}_{2}$ will lead to passivation in the oxygen deficiency and/or the low-level trap states generated at the time of material synthesis due to unsaturated Ti(III), and hence boost the performance.

Minimizing the Interface Recombination by Passivating Layer/Element between ETL and Perovskite

Various research groups have tried and succeeded in the modification of the $\mathrm{TiO}_{2}$ based ETL for effective charge extraction. Seo et al. in their work used mesoporous $\mathrm{TiO}_{2}$ based architecture with the $\mathrm{TiO}_{2}$ nanoparticles of $200 \mathrm{~m}^{2} / \mathrm{g}$ surface area which is much larger than what have been used till now in the conventional mesoporous based devices $\left(60 \mathrm{~m}^{2} / \mathrm{g}\right)$. The large area facilitates better contact with the perovskite giving efficient extraction. In addition, they modified the nanoparticle surface with the doping of Cs-halide. The doping with Cs based halide saturates the oxygen vacancies present on the surface by reducing the Ti(IV) into Ti(III). By the modification they were able to achieve a PCE of $21 \%$ [74]. Snaith et al. [75] also implemented the modification of the surface of c- $\mathrm{TiO}_{2}$ by Caesium Bromide ( $\mathrm{CsBr}$ ) coating, inhibiting the UV induced degradation. It also enhances the efficiency by providing improved electron transfer rate. In a similar approach, Sun et al. reported silane modification on the $\mathrm{TiO}_{2}$ surface which absorbs UV radiation as well as improves the film quality [76].

Another study performed to passivate the interface defect sites by Hairen et al. showed the improved efficiency of $20.1 \%$ for small area devices using $\mathrm{Cl}$ capped $\mathrm{TiO}_{2}$ nanocrystals in mixed cation (FA and MA) halide (I and $\mathrm{Br}$ ) based perovskites. In the figures of charge recombination lifetimes collected by them, $\mathrm{Cl}-\mathrm{TiO}_{2} \mathrm{NCs}$ shows almost double the lifetime $(145 \mu \mathrm{s})$ when compared to pure $\mathrm{TiO}_{2}(65 \mu \mathrm{s})$. $\mathrm{Cl}$ capping in the $\mathrm{TiO}_{2}$ helps in the surface passivation of the perovskite film by inhibiting the trap state formation leading to reduced recombination losses. By employing the same ETL to CsMAFA based perovskite, a high efficiency of $21.4 \%$ was achieved for small area devices [77].

Hao li and co-workers demonstrated a new carbon quantum dot and $\mathrm{TiO}_{2}$ based electron transport layer for better charge extraction. Introduction of Carbon $\mathrm{QDs}$ in $\mathrm{TiO}_{2}$ gives rise in the current values indicating efficient charge transport from perovskite to $\mathrm{TiO}_{2}$. They observed that the increase in the wt $\%$ of CQDs in the $\mathrm{TiO}_{2}$ prompts the charge transport but overall device performance will be improved with $10 \%$ (by weight) CQD incorporation in $\mathrm{TiO}_{2}$. However, they did not notice any chemical bonding between quantum dots and $\mathrm{TiO}_{2}$ in XPS studies inferring that CQDs acts as spacer between them. The best cell efficiency obtained was $18.9 \%$ with the Jsc and Voc values of $21.36 \mathrm{~mA} / \mathrm{cm}^{2}$ and $1.14 \mathrm{~V}$ respectively [78]. In the same direction, Jun et al. used PMMA:PCBM ultrathin layer at ETL/perovskite interface in mesoporous based perovskite device. They identified that the use of PMMA passivates the dangling bonds at the interface but simultaneously lowers the conductivity of the device. Addition of PCBM is used to balance this conductivity loss. Correct ratio of PMMA:PCBM (1:3) mixture showed the best cell efficiency of $20.4 \%$ [79].

Wenzhe Li et al. showed that inter-facial adjustments could lead to increased efficiency (and resilience) in perovskite solar cells, since the layers have small surface areas. They used a Caesium Bromide layer between the electron collection layer and the absorber layer of perovskite. This lead to an increased efficiency and stability of the solar cell: Firstly, this layer reduces the work function of $\mathrm{TiO}_{2}$. Secondly, it inhibits the degradation of the perovskite layer because of UV rays. Thirdly, it increases the electron transfer rate from perovskite to c- $\mathrm{TiO}_{2}$ [75].

Severin et al. summed up that $t \mathrm{BP}$ (4-tert-butylpyridine) adsorbs to the $\mathrm{TiO}_{2}$ surface increasing the $\mathrm{V}_{\mathrm{oc}}[80]$. There is a negative shift in the energy bands of $\mathrm{TiO}_{2}$ reducing the recombination rate which implies long charge carrier lifetime, and hence the efficiency is increased. Song et al. demonstrated that when $40 \mathrm{~nm}$ thick $\mathrm{A}-\mathrm{TiO}_{2}$ (prepared by a potentio-static anodization method) is deposited on FTO glass, the efficiency is maximum [81], a $22 \%$ increase from $12.5 \%$ to $15.2 \%$. 
Replace the Existing $\mathrm{TiO}_{2}$ Layer with New ETLs

$\mathrm{TiO}_{2}$ is widely used but it is associated with the flaw of high temperature annealing which is one of the limiting factors in its commercialization. In addition, the device instability under UV irradiation for longer times has been a critical parameter. Snaith's group in 2011 reported the advantages of tin oxide as an electron collecting layer as compared to $\mathrm{TiO}_{2}$ [82]. $\mathrm{SnO}_{2}$ provides the benefits of low temperature annealing, relatively higher band gap of $3.2 \mathrm{eV}$, and has better electron mobility (100 times faster than $\mathrm{TiO}_{2}$ ). Its deep level conduction edge facilitates faster charge transport from absorber layer to ETL. Qi Jiang and co-workers reported a PSC device of $20 \%$ efficiency with $\mathrm{SnO}_{2}$ based ETL while showing that the hysteresis can be lowered to a much greater extent in $\mathrm{SnO}_{2}$ based device [83]. The device could be produced at under $150{ }^{\circ} \mathrm{C}$ and utilized a $\mathrm{PbI}_{2}$ passivation phase in the perovskite layer, thus showing that meso-porosity can be replaced for high efficiency devices. In an approach Zhu et al. researched the use of $\mathrm{SnO}_{2}$ Nanocrystals as an ETL which provides good efficiency while retaining $90 \%$ of the initial PCE after 30 days of exposure to ambient conditions with RH $70 \%$ [84]. Recently, they also synthesized a new ETL material named c-HATNA. Utilizing this ETL, they were able to achieve high device performance with a PCE of 18.21\% [85]. Similarly, a new bilayer ETL has been proposed by Escobar et al. in which they have reported a combination of $\mathrm{ZrO}_{2}$ nanoparticles and $\mathrm{TiO}_{2}$ compact layer. The concept reduces any possibility of short circuiting between perovskite and $\mathrm{TiO}_{2}$. With the combination, they witnessed a stabilized power output of $17.0 \%$ with almost no hysteresis [86]. Due to the high temperature requirements in the fabrication of $\mathrm{TiO}_{2}$, organic charge-transport materials were employed as ETL. PCBM was reported as a possible replacement for $\mathrm{TiO}_{2}$ providing the advantage of room-temperature fabrication [87]. Jangwon and co-workers [88] reported a $14.1 \%$ efficient single unit cell device with PCBM as electron transport layer using a $\mathrm{p}-\mathrm{i}-\mathrm{n}$ architecture. A buffer layer was also introduced between PCBM and Al electrode which helps in better performance of the device by reducing the energy barrier between them. The PCE dropped to $8.7 \%$ when the architecture was employed on a large substrate of $10 \times 10 \mathrm{~cm}^{2}$ area. Low temperature PSCs utilizing nanocomposites of graphene and $\mathrm{TiO}_{2}$ nanoparticles were reported with an efficiency of $15.6 \%$ to counter the sintering requirement (by using a solution-based deposition method) [89].

\subsubsection{Miscellaneous Studies}

\section{Hysteresis}

A major component in the energy loss of PSC, which leads to a lower efficiency is the hysteresis loop. The studies conducted by Dualeh et al. (2013) [90] and snaith et al. (2014) [91] show that hysteresis is dependent on the scan rates used during current-voltage measurements, although the relationship found was contradictory in the two cases. Hysteresis loss is a function of pinhole formation and other faults in perovskite solar cells. Majority of these losses in the PSC are dependent on the morphology of the film, which is difficult to control. This has been attributed to slow transient capacitive current, dynamic trapping and de-trapping processes, and band bending due to ion migrations or ferroelectric polarization, as reviewed by Bo Chen et al. [92]. Rafael S. Sanchez et al. [93] detected slow dynamic processes in lead halide PSCs with a low frequency characteristic time which cannot be attributed to recombination processes in the cell and are correlated with J-V hysteresis. Wu et al. proposed the presence of a majority carrier bottleneck at either one or at both the perovskite/transport layer interfaces, combined with recombination at that interface, as the cause of hysteresis [94]. Shao et al. (2014) [95] showed that photocurrent hysteresis in the perovskite device could be eliminated by fullerene passivation using PCBM. According to their studies, trap sites on the surface and at grain boundaries of the perovskite material can be the reason behind the hysteresis. However, it has been posited that further research is required for a complete understanding of the science behind the hysteresis; therefore, controlled experiments have been suggested to probe the interstitial and interface causes of hysteresis [96]. 
Role of 4-tert-ButylPyridine

Habisreutinger et al. [80] investigated the role of 4-tert-ButylPyridine in perovskite solar cells. They concluded that the inclusion of tBP in perovskite solar cells leads to an increase in the steady-state efficiency of the cell. By deconstructing the solar cell, it was found that tBP interacts with the perovskite to make it more selective for holes, thus the entire study becomes independent of the hole-transporting material used. Since tBP is used on $p$-type side of the cells, the solar cells can be made more efficient by studying the tBP and perhaps similar chemicals which could make Perovskite more selective to hole selection.

\section{Graded Band-Gap PSC}

A new concept of graded band-gap perovskite solar cells has been added to the field by Ergen et al. They achieved this based on an architecture of two perovskite layers $\left(\mathrm{CH}_{3} \mathrm{NH}_{3} \mathrm{SnI}_{3}\right.$ and $\mathrm{CH}_{3} \mathrm{NH}_{3} \mathrm{PbI}_{3-\mathrm{x}} \mathrm{Br}_{\mathrm{x}}$ ) incorporating $\mathrm{GaN}$, Boron Nitride, and graphene aerogel, reporting an efficiency maximum of $21.7 \%$ [97].

\section{Method of Film Fabrication}

There have been several modifications in the method of perovskite film fabrication itself. Most recently, Ayi et al. [98] used a two-step spin-coating method for the preparation of perovskite film with varied spinning speed, spinning time, and temperature. They created a pin-hole free film with large grain size at room temperature with spinning speed $1000 \mathrm{rpm}$ for $20 \mathrm{~s}$ which was annealed at $100{ }^{\circ} \mathrm{C}$ for $300 \mathrm{~s}$. In 2015, Nie et al. [25] used a hot casting technique to grow continuous, pinhole-free perovskite films with millimetre-scale crystalline grains. The hot casting was done at a temperature of $180^{\circ} \mathrm{C}$ which resulted in large crystalline grains. The group reported an efficiency of up to $18 \%$ with roughly $2 \%$ variability and no hysteresis loss, which they attributed to the superb morphology of the perovskite film formed. Thus, the two processes have shown the difference in perovskite formation and the utility of perovskite as a substance is liable to constant change. For example, recently, Fei Han et al. [99] used a dissolution-recrystallisation method (first time reported) to improve device performance. They tested four combinations of DRM and found DRM-2 $(4 \mu \mathrm{L}$ DSMO and $96 \mu \mathrm{L}$ chlorobenzene) to give the most efficient cell with an efficiency of $16.76 \%$ compared with $13.81 \%$ for only chloro-benzene treated devices. There was a high level of reproducibility as well, with most devices showing a PCE of $15-17 \%$. The SEM scans revealed lesser defects and grain boundaries thus improving the $\mathrm{TiO}_{2}$ /perovskite interface as well.

\section{Transitioning from Lead to Other Elements}

Because of the toxic nature of lead, one of the challenges for perovskite researchers is to utilize other elements in the place of lead while keeping the perovskite structure and properties identical. The choice of element is dependent theoretically on the Goldschmidt tolerance factor [100] and practically on the formation of black perovskite [101]. Yao et al. [102] tested the optoelectronic properties of a Lead substituted Strontium based perovskite solar cell for different amount of strontium substitution. They found a positive effect on the thermal stability and output voltage $(1.11 \mathrm{~V}$ as opposed to $1.07 \mathrm{~V}$ in the device without doping) with a $=0.05$ amount of Strontium substitution, where "a" represents the stoichiometric coefficient of strontium in the material. The maximum efficiency achieved was $16.3 \%$. In another study, Eperon et al. [103] reported a method to form pure black phase $\mathrm{FAPbI}_{3}$ infiltrated into mesoporous scaffolds while also enhancing the performance of single cation solar cells. Their study focused on treating $\mathrm{MAPbI}_{3} / \mathrm{FAPbI}_{3}$ with solutions of formamidinium or methylammonium iodide to tune the band gap of perovskite to $1.48-1.57 \mathrm{eV}$. 
Inverted Structure of Perovskite

Apart from the above discussion, another important aspect is the use of inverted Perovskite cell structure where the positions of ETL and HTL are interchanged. This structure has been derived from organic solar cells and has been a successful transfer [104]. Due to the low hysteresis and simple fabrication method involved, inverted PSC ( $p$-type layer at front) is worthy of investigation [105]. Recently, Wu et al. [106] reported a PCE of $18.21 \%$ within an aperture area of $1.022 \mathrm{~cm}^{2}$, for an inverted PSC which had a perovskite-fullerene graded heterojunction. The concept of perovskite-fullerene bulk hetero-junction to enhance photo-electron collection was employed though the PCBM distributed within the perovskite in a gradient. Perovskite-fullerene bulk hetero-junction has previously been reported to enhance performance [107].

\subsubsection{Perovskite-Tandem Solar Cell}

Presently, researchers are looking at ways to fabricate high efficiency tandem solar cells (TSCs). These solar cells are usually created by an interconnection between a top perovskite cell and a bottom silicon (or other inorganic material) solar cell. Perovskite has been shown to be an ideal tandem material because it matches the three required criteria: solution processable, large bandgap, low energy losses [108]. There are different possible configurations in tandem solar cells (Figure 3): series tandem, module tandem, and four-terminal tandem; among these the four-terminal tandem is expected to have the highest efficiency. The architecture can also be divided into three types, as shown in Figure 4. Limiting efficiency for TSCs has been shown to be around $68.2 \%$ for an infinite number of sub-cells (under one sun illumination) [109], while efficiencies of $45 \%$ have been shown for the three configurations [110].

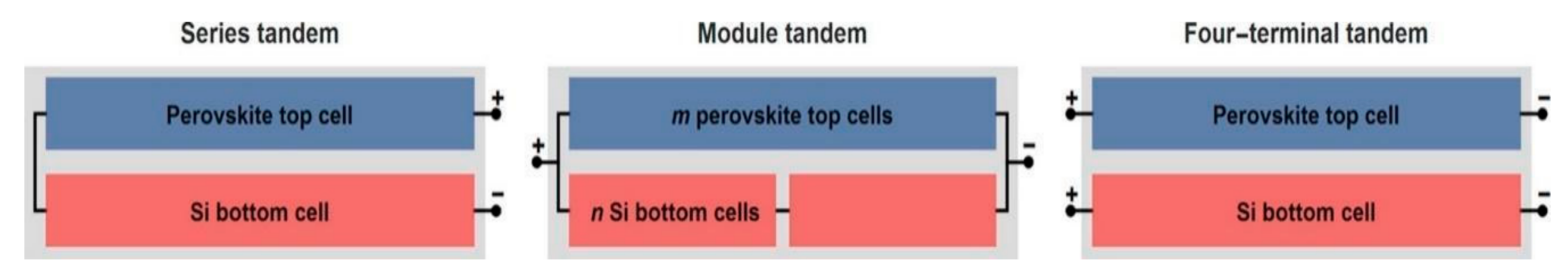

Figure 3. Si-Perovskite Tandem configurations, characterised by the number and connection of Perovskite and Silicon solar cell. Figure Taken from Futscher et al. [100].

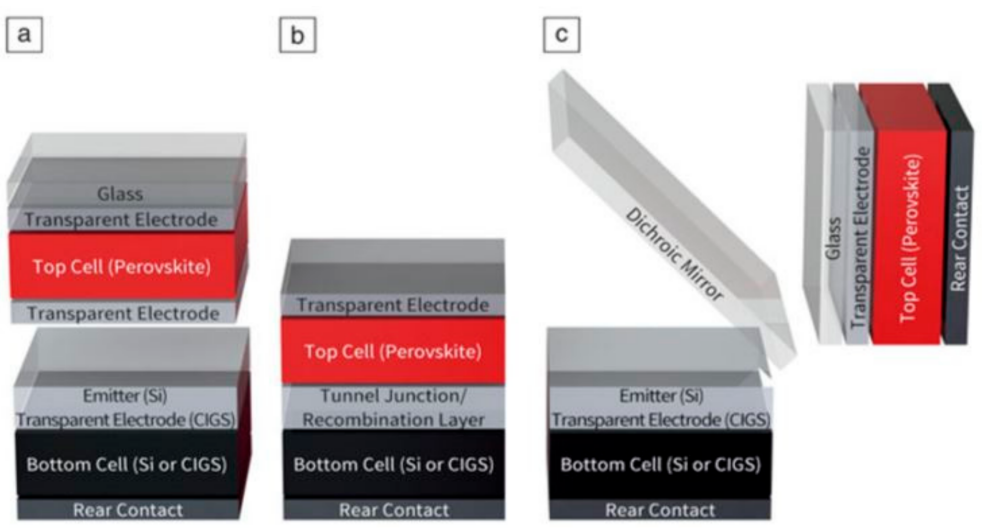

Figure 4. Tandem architecture in terms of internal stacking: (a) mechanically Stacked; (b) monolithically integrated; and (c) spectrally split. Taken from Bailie et al. [108].

The maximum efficiency for tandem solar cells has been reported to be around $28 \%$ utilizing an optical splitting system which splits light of different wavelengths and transports it to respective cells [111]. Hence, the splitting makes possible the usage of different cells in their respective bandgaps. 
TSCs include perovskite along with Kesterite $\left(\mathrm{Cu}_{2} \mathrm{ZnSn}(\mathrm{S}, \mathrm{Se})_{4}\right)$ [112], crystalline silicon [113-116], Copper Indium Gallium Selenide [117], and recently even perovskite with perovskite [118] where it was pointed out that there was need for high-performance low bandgap perovskite solar cells. A recent field which is also progressing is polymer-based organic photovoltaic cells which enable solution-processable tandem solar cells [119].

In 2015, Mailoa et al. [115] fabricated a two-terminal perovskite/silicon multi-junction solar cell, but it was only able to reach an efficiency of $13.7 \%$, signalling the need for more research so that the potential could be tapped into, which was concluded to be dependent on more efficient silicon and perovskite cell layers. Later, Fan Fu et al. [120] fabricated a $\mathrm{CH}_{3} \mathrm{NH}_{3} \mathrm{PbI}_{3}$ layer over $\sim 100 \mathrm{~nm}$ compact $\mathrm{ZnO}$ layer and $\sim 50 \mathrm{~nm}$ PCBM. This electron transport layer was low-cost, lightweight, and compatibile with monolithic tandem fabrication. Further, Spiro-OMeTAD was spin coated onto that followed by deposition of $60 \mathrm{~nm}$ gold contact by thermal evaporation. In addition, PCBM below perovskite smoothened the surface and eradicated the J-V hysteresis. The device showed an open-circuit voltage of $1.101 \mathrm{~V}$, short-circuit current of $17.6 \mathrm{~mA} \mathrm{~cm}^{-2}$ and a fill-factor of $74.9 \%$, resulting in a PCE of $14.5 \%$. When perovskite was mechanically stacked over the CIGS solar cell, the efficiency jumped to $20.5 \%$. The JSC of the CIGS cell was found to decrease because of reduced light intensity.

Bush and co-workers [4] fabricated monolithic perovskite/silicon tandem solar cells to reach an efficiency of $23.6 \%$ with zero hysteresis. They improved upon previous tandem solar cells by combining caesium formamidinium lead halide perovskite (band-gap of $1.63 \mathrm{eV}$ ) with an infrared-tuned silicon hetero-junction bottom cell (which had a rear-reflector of silicon nanoparticles). As reported, the final solar cell had a $\mathrm{V}_{\mathrm{oc}}$ of $1.65 \mathrm{~V}$, a J $\mathrm{J}_{\mathrm{sc}}$ of $18.1 \mathrm{~mA} / \mathrm{cm}^{2}$, and a fill factor of $79 \%$ with a $1 \mathrm{~cm}^{2}$ aperture area and no hysteresis. Furthermore, the stability of the tandem cells also increased because of the ITO employed which trapped the volatile methylammonium cation, thus reducing its degradation. The authors tested the tandem cell for more than $1000 \mathrm{~h}$ in a temperature of $85{ }^{\circ} \mathrm{C}$ and $85 \%$ relative humidity. It was also able to sustain maximum power for 30 min under constant illumination. They concluded that performance could be increased by widening the band-gap of the perovskite and reducing front-surface reflections.

David P. McMeekin et al. [121] used a metal halide perovskite cell in tandem with a silicon bottom cell to show that four terminal tandem cells of efficiencies greater than $25 \%$ may be obtained. The main perovskite cell employed caesium instead of the formamidinium cation to get a tunability of band-gap to around $1.75 \mathrm{eV}$ (eliminating the instability region of iodine to bromine phase change) which had a PCE of over $19 \%$. While greater efficiencies have been reported in single terminal perovskite cells, this solar cell serves better in the case of tandem solar cells by increasing the band-gap from the conventional $1.55 \mathrm{eV}$ to $1.75 \mathrm{eV}$.

\subsection{Long Term Device Stability}

\subsubsection{Degradation Mechanisms}

\section{Moisture Degradation}

It is evident that stability of the perovskite solar cell is one of the major factors that needs to be addressed before industrial application of this technology begins. Perovskite solar cells are inherently very sensitive to ambient operating conditions. Their performance starts deteriorating once they are exposed to moisture, UV radiation, and an increase in temperature. Degradation of the device is attributed mainly to the degradation of the perovskite layer itself or the degradation of interfacial layers. Among all factors, humidity is the biggest felon in the degradation of hygroscopic perovskite film. Exposure of perovskite film to humid environment leads to its hydration eventually resulting in the loss of performance. Leguy et al. found that hydration leads to formation of monohydrate and dihydrate phase of perovskite [122]. The hydrate formation mechanism can be understood by the following equations:

$$
\mathrm{CH}_{3} \mathrm{NH}_{3} \mathrm{PbI}_{3}+\mathrm{H}_{2} \mathrm{O} \rightarrow \mathrm{CH}_{3} \mathrm{NH}_{3} \mathrm{PbI}_{3} \cdot \mathrm{H}_{2} \mathrm{O}
$$




$$
4\left(\mathrm{CH}_{3} \mathrm{NH}_{3} \mathrm{PbI}_{3} \cdot \mathrm{H}_{2} \mathrm{O}\right) \rightarrow\left(\mathrm{CH}_{3} \mathrm{NH}_{3}\right)_{4} \mathrm{PbI}_{6} \cdot 2 \mathrm{H}_{2} \mathrm{O}
$$

Upon prolonged exposure to moisture, excess amount of water leads to formation of lead iodide by dissolving the methylammonium iodide part.

$$
\left(\mathrm{CH}_{3} \mathrm{NH}_{3}\right)_{4} \mathrm{PbI}_{3} \cdot 2 \mathrm{H}_{2} \mathrm{O} \rightarrow 4 \mathrm{CH}_{3} \mathrm{NH}_{3} \mathrm{I}(\mathrm{aq})+\mathrm{PbI}_{2}(\mathrm{~s})+2 \mathrm{H}_{2} \mathrm{O}(\mathrm{aq})
$$

However, Neu et al. in their report had shown the direct decomposition of perovskite into MAI and lead iodide on exposure to UV illumination coupled with air (containing oxygen and moisture), without any intermediate hydrated phase [123].

$$
\begin{gathered}
\mathrm{CH}_{3} \mathrm{NH}_{3} \mathrm{PbI}_{3} \leftrightarrow \mathrm{CH}_{3} \mathrm{NH}_{3} \mathrm{I}(\mathrm{aq})+\mathrm{PbI}_{2}(\mathrm{~s}) \\
\mathrm{CH}_{3} \mathrm{NH}_{3} \mathrm{I}(\mathrm{aq}) \leftrightarrow \mathrm{CH}_{3} \mathrm{NH}_{2}(\mathrm{aq})+\mathrm{HI}(\mathrm{aq}) \\
4 \mathrm{HI}(\mathrm{aq})+\mathrm{O}_{2} \leftrightarrow 2 \mathrm{I}_{2}(\mathrm{~s})+2 \mathrm{H}_{2} \mathrm{O} \\
2 \mathrm{HI}(\mathrm{aq})+\mathrm{h} v \leftrightarrow \mathrm{H}_{2} \uparrow+\mathrm{I}_{2}(\mathrm{~s})
\end{gathered}
$$

Decomposition of MAI gives $\mathrm{CH}_{3} \mathrm{NH}_{2}$ and $\mathrm{HI}$ [124]. $\mathrm{HI}$ further decomposes into $\mathrm{H}_{2}, \mathrm{I}_{2}$ and $\mathrm{H}_{2} \mathrm{O}$ on exposure to oxygen and illumination [125].

\section{Light Induced Degradation}

Another factor influencing the stability of perovskite solar cell device is UV light exposure. Charge collection efficiency of the device is severely limited with UV irradiation. The reason for this deterioration is the presence of deep charge trap states on the $\mathrm{TiO}_{2}$ surface. These sites adsorb the oxygen in the atmosphere and act as a recombination site for the hole generated upon shining of ultraviolet light. Desorption of oxygen from these sites leads to trapping of the electron from the conduction band of $\mathrm{TiO}_{2}$. The trapped electrons on these deep defect sites can easily recombine with holes available in the HTM and perovskite layer thereby resulting in a drastic drop in charge carrier collection efficiency [126].

In principal, passivation of these trap states and avoiding $\mathrm{UV}$ to reach to $\mathrm{TiO}_{2}$ are the basic solution to suppress the UV light degradation. Thus far, there are three methods to bypass the problem: either pacify the trap sites or avoid UV light from reaching the $\mathrm{TiO}_{2}$ or replace the $\mathrm{TiO}_{2}$ with another material.

\section{Thermal Degradation}

Increased temperature during operational conditions also causes instability of the perovskite film. High temperature exposure causes decomposition of $\mathrm{CH}_{3} \mathrm{NH}_{3} \mathrm{PbI}_{3}$ into its constituents [127]. Perovskite decomposes to give $\mathrm{PbI}_{2}$ which accumulates as a yellow phase between the layers of the cell and is orthorhombic and non-perovskite in structure. This decomposition of the perovskite is accelerated when temperature is increased further and is observed even in an inert environment (with argon). The $\mathrm{PbI}_{2}$ is stable within the layers of perovskite solar cell, but it leads to a decrease in overall stability. Conings et al. demonstrated the decomposition of perovskite after heating at $85^{\circ} \mathrm{C}$ for $24 \mathrm{~h} \mathrm{[128].} \mathrm{It} \mathrm{has} \mathrm{been} \mathrm{observed} \mathrm{that} \mathrm{under} \mathrm{exposure} \mathrm{to} \mathrm{much} \mathrm{lower} \mathrm{temperatures} \mathrm{MAPbI}_{3}$ converts to $\mathrm{PbI}_{2}$. According to recent studies performed by Kim and his co-workers on exposure to temperatures greater than $100{ }^{\circ} \mathrm{C}, \mathrm{MAPbI}_{3}$ decomposes into $\mathrm{PbI}_{2}, \mathrm{CH}_{3} \mathrm{I}$, and $\mathrm{NH}_{3} . \mathrm{PbI}_{2}$ remains whereas $\mathrm{CH}_{3} \mathrm{I}$, and $\mathrm{NH}_{3}$ evaporate [129]. They also elucidated that prolonged exposure to $80^{\circ} \mathrm{C}$ results in degradation of perovskite. They established the fact that organic MA cation plays a critical role in the thermal induced degradation since a change in the orientation as well as decomposition of MA on exposure to thermal stress is observed. Thus, replacing it with some inorganic cation can be beneficial in improving thermal stability. 


\subsubsection{Improving the Stability of Perovskite Solar Cells}

Globally, researchers are trying hard to achieve highly efficient and at the same time highly stable perovskite solar cells. Many attempts have been made to impart stability to the perovskite solar cell. Thus far, researchers have succeeded to achieve the stability of more than one year in perovskite solar cells [130]. The various possible ways discovered to impart stability to the perovskite solar cells are: (i) by altering the perovskite material since $\mathrm{MAPbI}_{3}$ is more prone to degradation; (ii) by providing hydrophobic HTL; (iii) by altering ETL so that UV induced degradation can be avoided; and (iv) by proper encapsulation of the device to avoid moisture ingress.

\section{By Altering the Perovskite Material}

Alteration of halide composition has proven to be an efficient way of improving stability. Tuning of divalent cation $\mathrm{A}$ and halide $\mathrm{X}$ in perovskite composition can make it more stable to the ambient environment. Mixed halide perovskite compositions generally incorporating $\mathrm{Br}$ in $\mathrm{MAPbI}_{3}$ have proven to be more stable in humid environments. Noh et al. showed that incorporation of $\mathrm{Br}$ in the $\mathrm{MAPbI}_{3}$ perovskite results in enhanced stability. [131] They have shown that when compared to the $\mathrm{MAPbI}_{3}$ perovskite degrading in a couple of hours, $\mathrm{MAPb}\left(\mathrm{I}_{1-\mathrm{x}} \mathrm{Br}_{\mathrm{x}}\right)_{3}$ with $\mathrm{x}=0.2$ was stable up to 20 days. According to them replacement of large Iodine ions with smaller $\mathrm{Br}$ ions results in cubic symmetry, which leads to enhanced stability. Jeon et al. also proved that $\mathrm{Br}$ incorporation into $\mathrm{MAPbI}_{3}$ results in an enhanced efficiency of $16.2 \%$ along with improved stability [132]. Although researchers have shown an enhancement in the moisture stability and stabilized crystal structure on incorporation of $\mathrm{Br}$, a study by Hoke and co-workers elucidated upon reversible light-induced phase transition in $\mathrm{Br}$ incorporated mixed halide perovskite. They believe that light soaking results in the generation of minority iodine-enriched and majority bromide-enriched phases, though dark exposure treatment can revert to the initial structure [133].

Some authors [134-136] have realized the use of pseudo-halogen for stability enhancement in $\mathrm{MAPbI}_{3}$ perovskite solar cell. Tai et al. [137] and Chen et al. showed that incorporation of lead (II) thiocyanate $\left(\mathrm{Pb}(\mathrm{SCN})_{2}\right)$ in the precursor leads to enhanced stability and performance. High-quality $\mathrm{CH}_{3} \mathrm{NH}_{3} \mathrm{PbI}_{3 \mathrm{x}}(\mathrm{SCN})_{\mathrm{x}}$ can be formed in humidity of more than $70 \%$ and with efficiency up to $15 \%$, maintaining $85 \%$ of the efficiency for more than $500 \mathrm{~h}$ without any encapsulation. This enhanced stability is attributed to the strong interaction between $\mathrm{Pb}^{2+}$ cation and the $\mathrm{SCN}^{-}$anion.

Stability can be enhanced by replacing the MA hygroscopic part with some other organic or inorganic cation with lesser sensitivity towards moisture. Larger formamidinium (FA) cation has shown to be more resistant to moisture and thermal degradation as compared to MA [138]. $\mathrm{FAPbI}_{3}$ perovskites have slightly lower bandgap $(1.48 \mathrm{eV})$ as compared to $\mathrm{MAPbI}_{3}(1.55 \mathrm{eV})$ providing even wider absorption, rendering it suitable for photovoltaic application [139]. $\mathrm{FAPbI}_{3}$ is reported to be unstable in the black $\alpha-\mathrm{FAPbI}_{3}$ phase at room temperature and a transition to yellow $\delta-\mathrm{FAPbI}_{3}$ photo-inactive phase is observed [140]. Tolerance factor of $\mathrm{FAPbI}_{3}$ is greater than 1, making the perovskite phase unstable and transition to yellow phase is quite favourable. This issue has been resolved by incorporation of smaller cation such as $\mathrm{Cs}$ and $\mathrm{Rb}$ into FA based perovskite to make the tolerance factor lie in the range 0.9-1 [141]. Due to entropic stabilisation, caesium assists the crystallization of black phase in FA based perovskite. Jeon et al. demonstrated that a combination of $\mathrm{FAPbI}_{3}$ and $\mathrm{MAPbBr}_{3}$, $\left(\mathrm{FAPbI}_{3}\right)_{1-\mathrm{x}}\left(\mathrm{MAPbBr}_{3}\right)_{\mathrm{x}}$ results in phase stabilization and enhanced efficiency of around $18 \%$ [142]. Yang et al. also elucidated that a mixture of FA and MA can yield highly efficient $(>19 \%)$ and structurally stable perovskite [143]. Another possible way of countering the instability issue could be the replacement of organic MA part with some inorganic cation. Caesium (Cs) is detected to be an acceptable alternative to organic MA cation by various research groups with enhanced moisture and thermal stability (stable up to $460^{\circ} \mathrm{C}$ ) [2] and suitable bandgap $(1.73 \mathrm{eV})$ required for solar cell applications [144]. In the initial studies, it was observed that the photoactive $\delta-\mathrm{CsPbI}_{3}$ phase is not stable below $315^{\circ} \mathrm{C}$, as there is a transition from black cubic $\delta$-CsPbI 3 phase to yellow orthorhombic $\alpha-\mathrm{CsPbI}_{3}$ phase. Till date various approaches have been discovered to stabilize the cubic $\delta-\mathrm{CsPb}_{3}$ 
phase. Eperon et al. showed that addition of hydroiodic in the $\mathrm{CsPbI}_{3}$ precursor results in formation of stable black $\delta-\mathrm{CsPbI}_{3}$ phase on annealing at $100{ }^{\circ} \mathrm{C}$ but with $1.7 \%$ PCE [145]. Recently, it has been observed that incorporation of sulfobetaine zwitterion (1.5 wt \%) in $\mathrm{CsPbI}_{3}$ precursor solution results in the formation of room temperature stable $\delta-\mathrm{CsPbI}_{3}$ phase. They found that plasma treated $\mathrm{CsPb}\left(\mathrm{I}_{0.98} \mathrm{Cl}_{0.02}\right)_{3}$ device leads to a stabilized PCE of $11.4 \%$, better than $\mathrm{CsPbI}_{3}$ device [144].

Further studies on Cs based perovskites, hunting for higher efficiencies, have also been positive. Saliba et al. presented that a triple Cs/MA/FA cation mixture perovskite can achieve an efficiency of $21.1 \%$ and maintains efficiency of about $18 \%$ under operational conditions after $250 \mathrm{~h}$. Adding Cs cation to MA/FA mixture suppresses yellow phase $\mathrm{PbI}_{2}$ impurities. In recent papers $[4,121] \mathrm{CsFA}\left(\mathrm{Cs}_{0.17} \mathrm{FA}_{0.83}\right.$ $\left.\mathrm{Pb}\left(\mathrm{Br}_{0.17} \mathrm{I}_{0.83}\right)_{3}\right)$ perovskite tandem cell was operated at humidity $40 \%$ and temperature $35{ }^{\circ} \mathrm{C}$. Even then the Device performed for over $1000 \mathrm{~h}$ of testing with minimum degradation. Caesium (5\%) induces more uniform grains thereby enhancing the better charge transport resulting in a higher fill factor [146]. Sun and co-workers showed that incorporation of $\mathrm{Pb}(\mathrm{SCN})_{2}$ in triple cation mixed halide perovskite $\mathrm{FA}_{0.7} \mathrm{MA}_{0.2} \mathrm{Cs}_{0.1} \mathrm{~Pb}\left(\mathrm{I}_{5 / 6} \mathrm{Br}_{1 / 6}\right)_{3}$ results in highly efficient and stable perovskite, and without the requirement of thermal annealing [147]. They have realized a room temperature flexible solar cell with an efficiency of $10.55 \%$. This opens a path for the realization of low temperature, highly efficient, stable, and flexible perovskite solar cells. Bu and co-workers successfully demonstrated a quadruple cation perovskite $\left(\mathrm{K}_{\mathrm{x}}\left(\mathrm{Cs}_{0.05}\left(\mathrm{FA}_{0.85} \mathrm{MA}_{0.15}\right)_{0.95} \mathrm{~Pb}\left(\mathrm{I}_{0.85} \mathrm{Br}_{0.15}\right)_{3}\right.\right.$ with enhanced efficiency and stability [148]. Partial substitution of the $\mathrm{B}$ site with $\mathrm{Bi}^{3+}$ has also proven to be an efficient way of stabilizing $\alpha-\mathrm{CsPbI}_{3}$ phase, retaining $68 \%$ of initial PCE after $168 \mathrm{~h}$ of exposure to ambient conditions without encapsulation [149].

Many 2D perovskites solar cells have been realized with better moisture stability but which compromise on the PCE [150]. Grancini et al. showed that 2D/3D perovskite junction interface engineering results in an extraordinary stability of more than one year [130]. They showed that an HTM free solar cell can be realized by substituting Spiro-OMeTAD and Au contact with carbon matrix in the proposed 2D/3D $\left(\mathrm{HOOC}\left(\mathrm{CH}_{2}\right)_{4} \mathrm{NH}_{3}\right)_{2} \mathrm{PbI}_{4} / \mathrm{MAPbI}_{3}$ perovskite junction solar cell. They elucidated that 2D perovskite layer functions as a protective window against moisture for the underlying efficient 3D perovskite layer, at the same time acting as barrier for electron recombination. In a recent study, Wang and co-workers also investigated a 2D/3D heterostructure by incorporating $n$-butylammonium cations into $\mathrm{FA}_{0.83} \mathrm{Cs}_{0.17} \mathrm{~Pb}\left(\mathrm{I}_{\mathrm{y}} \mathrm{Br}_{1-\mathrm{y}}\right)_{3}$ perovskite leading to enhanced efficiency and stability [151]. They found an average PCE of $17.5 \pm 1.3 \%$ and retention of $80 \%$ PCE in ambient environment for 1000 and $4000 \mathrm{~h}$ with encapsulation.

By Altering the ETL

Usually, $\mathrm{TiO}_{2}$ is used as an electron transport layer (ETL) in perovskite solar cells. Batmunkh and co-workers modified the $\mathrm{TiO}_{2}$ ETL by incorporating Single-Walled Carbon Nano-Tubes (SWCNTs) in the $\mathrm{TiO}_{2}$ NPs and sandwiching this layer between compact $\mathrm{TiO}_{2}$ and perovskite layer [152]. They witnessed an increase in the light stability because SWCNT are highly conducting and they provide alternative paths for electrons to travel. This way they do not get trapped in the deep trap states developed in $\mathrm{TiO}_{2}$ on light exposure. Air stability is also enhanced as CNTs are hydrophobic so they do not allow the adsorption of moisture onto $\mathrm{TiO}_{2}$ surface, which might lead to degradation of on grown perovskite film. These surface modifications improve the stability under UV light as well as enhance the efficiency of the device through passivation. Pathak et al. demonstrated that Neodymium doped $\mathrm{TiO}_{2}$ has increased conductivity [153]. Only $0.3 \%$ doping of $\mathrm{Nd}$ in $\mathrm{TiO}_{2}$ passivates all the non-stoichiometry defects resulting in increased device performance. PSC prepared with Nd-doped $\mathrm{TiO}_{2}$ electrodes have higher early-time stability without affecting the short-circuit current. Lifetime of the encapsulated devices is improved with neodymium doping.

Replacement of $\mathrm{TiO}_{2}$ with $\mathrm{ZnO}$ had also been tried by Yang et al. and it turned out be more thermally unstable than $\mathrm{TiO}_{2}$ [154]. The reason behind it is that $\mathrm{ZnO}$ consists of deep trap states caused by electrons hopping from perovskite LUMO and might cause trap assisted recombination, 
resulting in performance loss. Mahmud et al. presented a method of modifying the surface of $\mathrm{ZnO}$ with Caesium Acetate (CA) and Caesium Carbonate (CC) showing improved stability and device performance [155]. They have elucidated that CA modified ETL in mixed organic cation $\mathrm{MA}_{0.6} \mathrm{FA}_{0.4} \mathrm{PbI}_{3}$ perovskite film shows a PCE of $16.45 \%$ and higher stability than CC modified one, when stored in controlled $\mathrm{N}_{2}$ ambient for 30 days under RH of $35-40 \%$. This is because CC ETL is more sensitive to humidity, causing easy moisture assisted degradation. Cao el al. studied modification of $\mathrm{ZnO}$ with a thin passivation layer of $\mathrm{MgO}$ and protonated ethanolamine (EA) with PCE of about $21.1 \%$ and stable up to $300 \mathrm{~h}$ [156]. MgO eliminates charge recombination and EA helps in efficient charge transport. M. Arafat Mahmud et al. also investigated the effect of adsorbed carbon derivatives, fullerene (C60) and $\mathrm{PC}_{71} \mathrm{BM}$ on the triple cation $\mathrm{MA}_{0.57} \mathrm{FA}_{0.38} \mathrm{Rb}_{0.05} \mathrm{PbI}_{3}$ perovskite and $\mathrm{ZnO}$ ETL interface [157]. They found that $\mathrm{C} 60$ modified device turned out to be more efficient and stable holding back $94 \%$ of initial PCE after one month of studies in $\mathrm{N}_{2}$ filled glove box without encapsulation. This enhancement is because of less hydrophilicity of $\mathrm{C} 60$ modified $\mathrm{ZnO}$ and passivation of trap states by intercalation of oxygen in the interstitial trap states of $\mathrm{ZnO}$. Pang and co-workers in a recent study have shown highly mesoporous $\mathrm{Zn}_{2} \mathrm{Ti}_{3} \mathrm{O}_{8}(\mathrm{~m}-\mathrm{ZTO})$ as an efficient ETL which retarded the interfacial recombination resulting in high efficiency [158]. The devices so formed displayed a decrease of just $12 \%$ on 100 days of exposure to $10 \% \mathrm{RH}$ and ambient temperature.

Wang and co-workers introduced a new ETL layer of cerium oxide. They reported that this $\mathrm{CeO}_{\mathrm{x}}(\mathrm{x}=1.87)$ based electron transport material can be processed at low temperatures and is equally efficient for electron extraction from perovskite absorber layer. Stability test showed that this material is more robust as compared to conventional $\mathrm{TiO}_{2}$ based ETL [159]. They also improvised a buffer layer of $\mathrm{PC}_{61} \mathrm{BM}$ between ETL and absorber to enhance the UV stability. Shin et al. testified replacement of $\mathrm{TiO}_{2}$ with Lanthanum (La)-doped $\mathrm{BaSnO}_{3}$ with enhanced efficiency of about $21.2 \%$ and retaining $93 \%$ of initial PCE after $1000 \mathrm{~h}$ of sun illumination [160].

Recently, Lee and co-workers tried replacing $\mathrm{TiO}_{2}$ ETL with Triton X-100 surface modified phenyl-C61-butyric-acid-methyl ester (PCBM) where $\mathrm{NiO}_{x}$ nanocrystals served the purpose of HTL [161]. They observed an increase in the average PCE from $10.76 \%$ to $15.68 \%$ along with an increase in the stability. PSC preserved $83.8 \%$ of the PCE after $800 \mathrm{~h}$ of exposure to ambient conditions. Jin Heo and co-workers investigated an inverted planar ITO/PEDOT:PSS/MAPbI $3 / \mathrm{PCBM} / \mathrm{Au}$ device with enhanced efficiency of about $18.1 \%$ along with air and moisture stability [105]. This improvement in stability is attributed to the top layer being exposed to PCBM ETL which is hydrophobic. Kim et al. demonstrated the use of an edged-selectively fluorine(F) functionalized graphene nanoplatelets (EFGnPs-F) layer between PCBM and Al electrode, exhibiting improved stability; being stable for 30 days at $50 \%$ humidity [162]. This is because of the hydrophobic nature of C-F bonding protecting the perovskite layer against moisture. Recently, Kim et al. showed high performance and stability with naphthalene diimide (NDI)-based polymer with dicyanothiophene (P(NDI2DT-TTCN)) as ETL [163]. $\mathrm{P}(\mathrm{NDI} 2 \mathrm{DT}-\mathrm{TTCN})$ improves the charge transfer and at the same time passivates the surface and increases moisture stability.

\section{By Providing Hydrophobic HTL}

Spiro-OMeTAD is usually used as a hole transporting material. This is doped with chemicals such as tert-butyl pyridine (tBP) and Li-bis(trifluoromethanesulfonyl)imide (Li-TFSI) for better conductivity. In the absence of $\mathrm{tBP}$, the film formation suffers from de-wetting and poor homogeneity [82]. These dopants increase the device performance and at the same time tBP absorbs moisture and dissolves $\mathrm{MAPbI}_{3}$, thus rendering it unstable in the ambient condition [164]. Many attempts have been made to design devices with dopant free HTL. Many other dopant free HTLs have been realized, e.g., triazatruxene, 5,10,15-tribenzyl-5H-diindolo[3,2-a:3', $\left.2^{\prime}-c\right]$-carbazole (TBDI) and other carbazole, thiophene [165], and triarylamine derivatives, thus avoiding the possibility of dopant induced degradation [166]. 
$\mathrm{Li}$ et al. recently proposed a cell structure employing a double-layer HTM configuration comprising of CuSCN layer and Spiro-OMeTAD layer for enhanced stability and efficiency [167]. Existence of pin holes in the as-deposited Spiro-OMeTAD layer have been observed by Hawash et al. which may provide sites for the migration of ions from the perovskite layer towards Spiro-OMeTAD, resulting in the degradation of device [168]. Thus, the CuSCN inorganic layer sandwiched between the perovskite and Spiro-OMeTAD blocks methyl amine ion migration into Spiro-OMeTAD. Kim et al. proposed a mixed hole transporting layer comprising of Spiro-OMeTAD and poly(3-hexylthiophene) (P3HT), exhibiting 18.9\% PCE and enhanced stability [169]. Ginting et al. showed that when $\mathrm{MAPbI}_{3}$ is decomposed, $\mathrm{HI}$ and $\mathrm{CH}_{3} \mathrm{NH}_{2}$ gases are released in the air [170].

Due to moisture $/ \mathrm{O}_{2}$, distribution of iodine concentration is affected within the $\mathrm{MAPbI}_{3}$ layer. This leads to the diffusion of iodine towards the Spiro-OMeTAD layer and it gets accumulated near the Spiro-OMeTAD $/ \mathrm{MAPbI}_{3}$ interface. Short circuit current and fill factor are adversely affected due to reduced carrier mobility. To address this issue, Snaith et al. [171] demonstrated a method to form HTL free perovskite solar cell by sequential deposition and observed that when single walled nanotube (SWNT)-PMMA is deposited sequentially on the perovskite film, SWNT forms a dense and interconnected network. PMMA matrix fills in all the holes between the nanotube mesh and protects the underneath perovskite film from moisture degradation. It has been concluded that the thickness of PMMA layer should be around $300 \mathrm{~nm}$. This is because thicker layers increase series resistance and reduce the charge collection efficiency, whereas thinner layers lead to an increased charge recombination and reduced shunt resistance. Similarly, Luo et al. studied usage of Cross-stacked super-aligned carbon nanotubes (CSCNTs) for an efficient and stable HTL free device [172]. Mei and co-workers fabricated (5-AVA) $(\mathrm{MA})_{1-\mathrm{x}} \mathrm{PbI}_{3}$ based $\mathrm{HTL}$ free perovskite device using mesoporous $\mathrm{TiO}_{2}, \mathrm{ZrO}_{2}$, and porous carbon tri-layer [173]. They demonstrated stability for $>1000 \mathrm{~h}$ in ambient air and illumination. Replacement of Spiro-OMeTAD with other equally efficient HTLs has been realized worldwide. According to a recent study performed by Chang et al. a $p$-type conjugated polymer poly[(2,5-bis(2-hexyldecyloxy)-phenylene)-alt-(5,6-difluoro-4,7-di(thiop-hen-2-yl)benzo[c]-[1,2,5]thiadiazole)] (PPDT2FBT) doped with a non-hygroscopic Lewis acid, tris(penta-fluorophenyl)borane (BCF, 2-6 wt \%) has been proven to be a much more efficient HTL than standard Spiro-OMeTAD [174]. They showed PCE up to $17.7 \%$ with standard $\mathrm{MAPbI}_{3}$ PSC and retaining $60 \%$ of the primary PCE upon exposure to $85 \%$ humidity for $500 \mathrm{~h}$ without any encapsulation.

Another commonly used HTL is poly(3,4-ethylenedioxythiophene):poly(styrenesulfonate) (PEDOT:PSS) but its acidic nature corrodes the ITO layer, and its hygroscopic nature causes the degradation of perovskite film. [171] These limitations combined with UV instability result in the irreversible deterioration of perovskite/PEDOT:PSS interface causing device degradation. Wang et al. [175] tried to solve this limitation of PEDOT:PSS by forming a bilayer HTL using Vanadium pentoxide $\left(\mathrm{V}_{2} \mathrm{O}_{5}\right)$ and PEDOT:PSS, showing a PCE of $15 \%$ (20\% more than when using conventional PEDOT:PSS HTL). After 18 days of stability testing, it was observed that the bilayer HTL based device retains 95\% of its initial PCE whereas PEDOT:PSS HTL device exhibits a retentivity of only $55 \%$. Recently, Shuang and co-workers investigated a mixture of hydrophobic polymer Nafion and PEDOT:PSS for better efficiency and highly enhanced stability than its PEDOT:PSS counterpart [176]. It acts as an electron blocking layer and avoids recombination hence increasing performance, and, at the same time, its chemical inertness and hydrophobicity enhance the stability in air.

Yang et al. studied the replacement of PEDOT:PSS with 4,4'-cyclohexylidenebis[N,N-bis(4-methylphenyl) benzenamine] (TAPC) as an efficient HTL in p-i-n $\mathrm{MAPbI}_{3}$ perovskite device with better PCE $(18.80 \%)$ and stability (retaining 6\% PCE after 30 days exposure to RH between 50 and $85 \%$ ) without encapsulation as compared to a conventional PEDOT:PSS device [177]. They have optimized the annealing temperature required and found it to be $120^{\circ} \mathrm{C}$ for better performance of the device.

Lee et al. demonstrated the use of a hydrophobic HTL, poly $\left(N, N^{\prime}\right.$-bis(4-butylphenyl)- $N, N^{\prime}$-bis (phenyl)benzidine) (PTPD), along with a thin hydrophilic layer of poly[(9,9-bis( $3^{\prime}$-( $N, N$-dimethylamino) propyl)-2,7-fluorene)-alt-2,7-(9,9-dioctylfluorene)](PFN) for enhanced stability retaining $\sim 80 \%$ PCE 
after 16 days of ambient exposure [178]. In this study they elucidated how the thin PFN layer, though hydrophilic, does not have any detrimental effect, but it results in a good morphology of the film, acting as a compatibilizer between perovskite and PTPD. PTPD is a hydrophobic HTL, so it restricts moisture interaction with perovskite film. Wang and his co-workers showed an inorganic $\mathrm{NiO}_{x}$ nanoparticles based HTL with para-bromobenzoic acid showing good stability, while maintaining $80 \%$ of its initial PCE after 15 days of exposure to $30 \%$ humidity [179]. This is accounted for the enhanced film morphology and passivation of defect states in $\mathrm{NiO}_{\mathbf{x}}$ by para-bromobenzoic acid. $\mathrm{NiO}$ as $\mathrm{HTL}$ has also proven to enhance thermal stability [180].

Petrozza et al. elucidated the enhancement in the stability of the solar cell when $\mathrm{Al}_{2} \mathrm{O}_{3}$ nanoparticles were put in between perovskite and HTL [181]. Addition of buffer layer improved the device efficiency as it reduces the thickness of HTL, decreasing the series resistance and as a result the Fill Factor increased. Similarly, Koushik et al. introduced an atomic layer deposited (ALD) ultra-thin layer of $\mathrm{Al}_{2} \mathrm{O}_{3}$ between the mixed halide $\mathrm{CH}_{3} \mathrm{NH}_{3} \mathrm{PbI}_{3-\mathrm{x}} \mathrm{Cl}_{\mathrm{x}}$ perovskite film and HTL for stability enhancement (up to 60 days) and an improved PCE of 18\% [182]. Hydrophobic ALD $\mathrm{Al}_{2} \mathrm{O}_{3}$ not only restricts the reach of moisture to the perovskite film but also passivates the defect states on the perovskite, making it more stable in moisture and oxygen.

\section{By Proper Device Encapsulation}

Owing to the moisture sensitivity of perovskite solar cells, proper encapsulation of the device is critical. Researchers worldwide have demonstrated many protective coatings to suppress the ingression of moisture into the perovskite layer. Depositing a protective layer of epoxy/Ag paint, CNTs, $\mathrm{Al}_{2} \mathrm{O}_{3}, \mathrm{Cr}_{2} \mathrm{O}_{3}$, and $\mathrm{ZnO}$ has proven to enhance the perovskite stability to a considerable amount [183-186]. Hwang et al. used a hydrophobic polymer Polytetrafluoroethylene as a perovskite shielding layer, showing negligible PCE loss after 30 days of ambient exposure [187]. Bush et al. used an ethylene-vinyl acetate (EVA) coated glass cover as an encapsulant, which is generally used in commercial silicon devices [4]. They sandwiched the perovskite layer between two glass sheets with EVA and butyl rubber edge seal to prevent moisture exposure. These Devices withstood damp heat test for $1008 \mathrm{~h}$ without any loss in PCE. Cheacharoen et al. compared EVA and Surlyn based encapsulation, and their tests proved EVA to be better because of its high mechanical stability due to low elastic modulus [188]. Liu et al. reported polydimethylsiloxane as an efficient encapsulant for

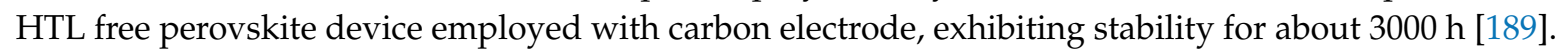
Matteocci et al. demonstrated a Kapton film covered with silicon based adhesive and UV curable methacrylate glue used for gluing glass-glass as an efficient encapsulant [190]. Han and his co-workers studied the comparison between two encapsulations: UV-curable epoxy and glass cover along with HG desiccant sheet in between [191]. They found the latter to be more stable under light and moisture exposure. Similarly, Dong and his co-workers testified various encapsulants and demonstrated UV-curable epoxy along with desiccant and an $\mathrm{SiO}_{2}$ protective layer as an efficient encapsulant [192]. Shi et al. used glass/polyisobutylene (PIB)/glass encapsulation, and the device remained for $540 \mathrm{~h}$ under damp heat without any loss in PCE [193]. PIB tape is used as a sealant and it protects moisture ingression as well as retarding the decomposition generated gaseous escape. This is also non-reactive to perovskite solar cell dissimilar to the UV-curable epoxy and EVA. Some other sophisticated encapsulants may open the scope for even better stability.

\section{Electrodes}

Conventionally, the PSC relies on Au, Ag, and Al based electrodes. However, due to Ag [191] and $\mathrm{Al}$ [192] not being as favoured because of stability issues, PSCs utilise more costly Au electrodes. Recent studies however have demonstrated the use of other materials such as $\mathrm{MoO}_{\mathrm{x}} / \mathrm{Al}$ electrodes that inhibit the decomposition of perovskite films [194], multi-walled carbon nanotubes that are more cost effective and stable than gold [195], and even $\mathrm{Cu}$ which has a predicted stability lifetime of over 22 years at the nominal operating cell temperature [196]. Kaltenbrunner et al. proposed $\mathrm{Cr}_{2} \mathrm{O}_{3} / \mathrm{Cr}-\mathrm{Au}$ 
metal contact for enhanced stability by shielding the Au contact from oxidation and chemical etching due to $\mathrm{MAPbI}_{3}$ released Iodine [185]. These studies are based on finding cost effective electrode materials which either do not degrade the perovskite film or do not trap electrons at the surface.

In recent years, however, the impact of stability improvements is also being seen a little in the marketplace, although it has yet to reach any public modules. Australian PSC developer Dyesol claimed a significant breakthrough in perovskite stability for commercial use [197]. Similarly, a few other companies such as Saule Technologies and Oxford Photovoltaics are also unveiling plans for future perovskite production at the commercial level [198].

\subsection{Cost of Fabricating Perouskite Solar Cell}

When it comes to overall solar and renewable energy, the world has seen a steep decrease in cost and it has been predicted that the costs will drop $66 \%$ by $2040[199,200]$. These predictions, however, are based on the performance of silicon based solar cells, as shown in Figure 5a,b. While it is well known and generally accepted that PSCs are low cost, very few techno-economic studies have been performed. However, recently, according to Cai's comparative cost-performance analysis on high efficiency and moderate efficiency PSCs, the Levelized Cost of Electricity (LCOE: defined as the ratio of total life cycle cost to total lifetime energy production) was 3.5-4.9 US cents/kWh with an efficiency of $12 \%$ and lifetime of 15 years (Figure 6 ) and the counterpart multi-Si cells (with an efficiency $>18.4 \%$ ) are estimated to have an LCOE of $\$ 0.23$ per watt [201-203].

According to calculations done by Maniarasu et al. [204] in the fabrication of one metre square perovskite solar cell with $70 \%$ active area, $52 \%$ of the total raw material cost is taken up by the hole transporting material (Spiro-OMeTAD—604 USD) and counter electrode (gold-330 USD), and $43 \%$ by FTO glass (766 USD). On the other hand, Perovskite layer takes only $0.0038 \%$ of the total cost. Therefore, any improvement in cost requires change of HTM and Electrode to cheaper alternatives, for example PCBM and Al, respectively. Pertinent to this, Petrus et al. suggested the use of azomethine-based HTMs-Diazo-OMeTPA [205] and EDOT-OMeTPA-for low cost and highly efficient PSCs. The studies revealed that Schiff-base condensation chemical synthesis for these HTMs, which is eco-friendly, attributes to the reduced cost in contradiction to coupling reactions (conventionally used to synthesize HTMs) [206]. Wu et al. developed electron rich HTMs with thiophene pi-linker claiming to reduce the synthesis cost by tenfold, in comparison with Spiro-OMeTAD, due to its shorter synthesis route [207]. Arylamine derivatives with pyrene core [208], two-dimensional triazatruxene-based derivatives [63], phenothiazine-based molecules [209], biphenyl based [210], bi- and tetra-thiophene based molecules [209,211], triazine based [212] HTMs could be a prospective replacement for Spiro-OMeTAD. Although polymeric HTMs such as PE-DOT:PSS and $\mathrm{P} 3 \mathrm{HT}$ are proven to be cost effective, their polydispersity results in variation in the molecular weight for batch to batch production, hindering their commercialization [213]. Chemically stable inorganic p-type semiconductors- $\mathrm{NiO}$ [214], CuSCN [215], and CuI [216] are often cheap due to inexpensive precursors and act as hole-extracting materials in PSCs, and yet they are least explored. Despite noble metals being widely used as counter electrodes for state-of-art devices, use of carbon-based materials can cut down the material cost for PSCs. Carbon in various forms, CNTs, graphitic sheets/flakes, fullerenes, and soot have been explored for this purpose. These materials offer flexibility of printing as well as solution-based processing, paving the path to scale up production. Composites of $p$-type semiconductors bent with carbon materials, for example $\mathrm{NiO}$ in carbon matrix [180,217], P3HT and PMMA blended with SWCNTs [218] exhibited a great potential as HTMs for low cost PSCs. 


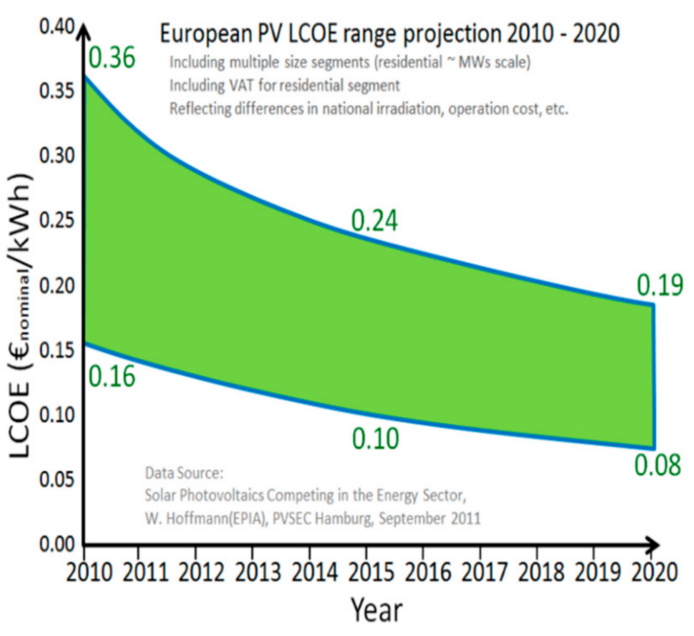

(a)

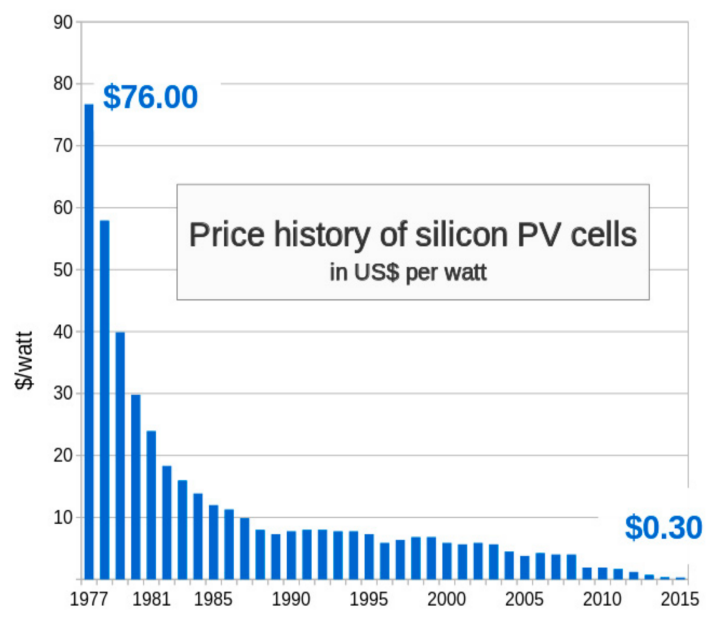

(b)

Figure 5. (a) LCOE range of photovoltaics (Europe); and (b) price history of silicon photovoltaics (Wikipedia.com).

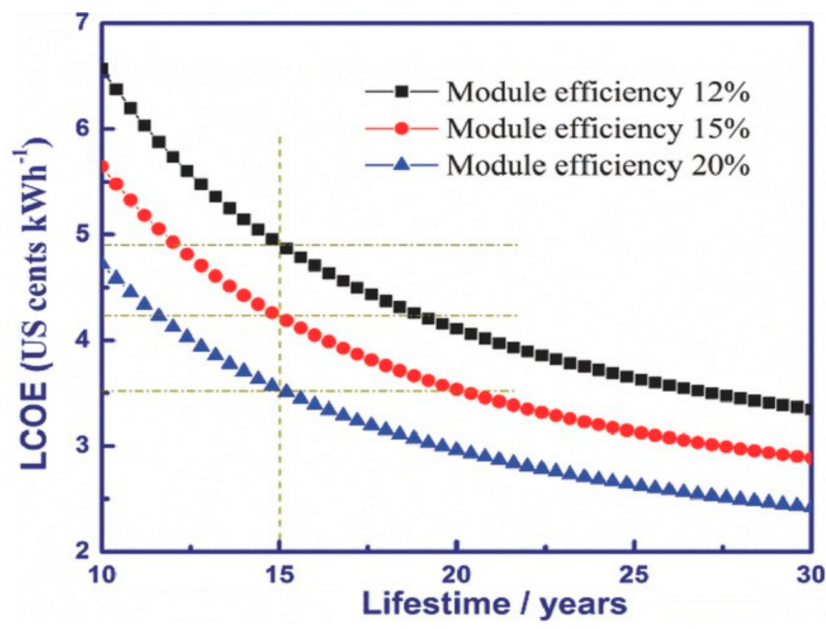

Figure 6. Effect of lifetime on LCOE, as a function of efficiency. As the lifetime increases, the LCOE goes drastically down but should reach a saturation point at the end (taken from Cai et al. [201]).

\section{Economic Feasibility of Perovskite Solar Cell}

\subsection{Energy Payback Time and Energy Return on Energy Invested}

An economical way of looking at solar cells is by comparing the energy payback time of different solar cells [219]. The EPBT determines the duration of time a PV system must operate before it recovers the amount of energy invested throughout its lifetime. Using the formula given by Bhandari et al. we have:

$$
\begin{gathered}
E P B T(\text { years })=\frac{\text { Embeded primary energy }(\mathrm{MJm}-2)}{\text { Annual primary energy generated by the system(MJ m-2 year }-1)} \\
=\frac{W_{1}}{(\mathrm{I} \times \eta \times \mathrm{PR} / \varepsilon)}
\end{gathered}
$$

where $W_{1}$ is the embedded primary energy; $\varepsilon$ is the electricity to primary energy conversion factor ( 0.35 usually); I is the total solar insolation incident on unit surface per year; $\eta$ is the average module efficiency; and PR is the system performance ratio.

According to the study carried out by Celik et al. [220] in 2016, only four Life cycle assessment studies had been done before them, where a life cycle study determines the energy usage of a solar 
cell during the entire process from creation to disposal. Using estimations and ideas about which type of perovskite solar cell would be used commercially in the future, Celik et al. did an ex-ante life cycle assessment including the EPBT of perovskite solar cells. The efficiency assumed was 15\%. The studies are shown in the graphic below along with the data on harmonized EPBT values of other solar cells. The fourth bar in Figure 7 combines the data of the previous studies with data for PCBM that we calculated, while the fifth bar has data for single walled carbon nanotubes based solar cells which have an estimated theoretical efficiency of $28 \%$. Gong et al. found an EPBT of 0.299 and 0.221 if $\mathrm{TiO}_{2}$ and $\mathrm{ZnO}$ are replaced by PCBM in the cell [88], and an EPBT of 0.964 and 0.721 if $\mathrm{SnO}_{2}$ is replaced by PCBM in the case of solution processed cell and HTL free cell thought of by Celik et al. The latter case is perhaps more interesting, as Gong's study does not utilise much electricity due to the processes involved (no annealing is done), which can further effect both the efficiency and the lifetime of the solar cells. Due to the lower amount of PCBM material used as compared to $\mathrm{SnO}_{2}(0.154 \mathrm{gm}$ as opposed to nearly $500 \mathrm{gm}$ of $\mathrm{Sn}$ ) and the low electricity requirement for the former, PCBM lowers the EPBT by nearly $25 \%$, assuming the same efficiency of the cell in the case of CuSCN HTL. On the other hand, when we have an HTL free device, the EPBT is even lower. Because Spiro-OMeTAD takes more energy than CuSCN, the latter is a better alternative, unless the cell is HTL free. The data for Spiro-OMeTAD and PCBM are from Espinosa et al. who did an LCA (Life-cycle assessment) study at the lab level [221] and from Annick Anctil [222].

Another way of looking at solar cell is to look at the EROI, or the energy return on energy invested, which is a function of EPBT and lifetime, given as [219]:

$$
E R O I=\frac{\text { Lifetime }(\text { years })}{\text { EPBT }(\text { years })}
$$

The EROI is presently set as a 3:1 ratio for any solar cell technology to be considered viable. Therefore, we can calculate the minimum requirement of lifetime for the solar cells used in the study to be considered as viable contenders by using the EPBT and studies in Figure 7. The resulting lifetimes when the EROI is set as 3 can be seen in Figure 8.

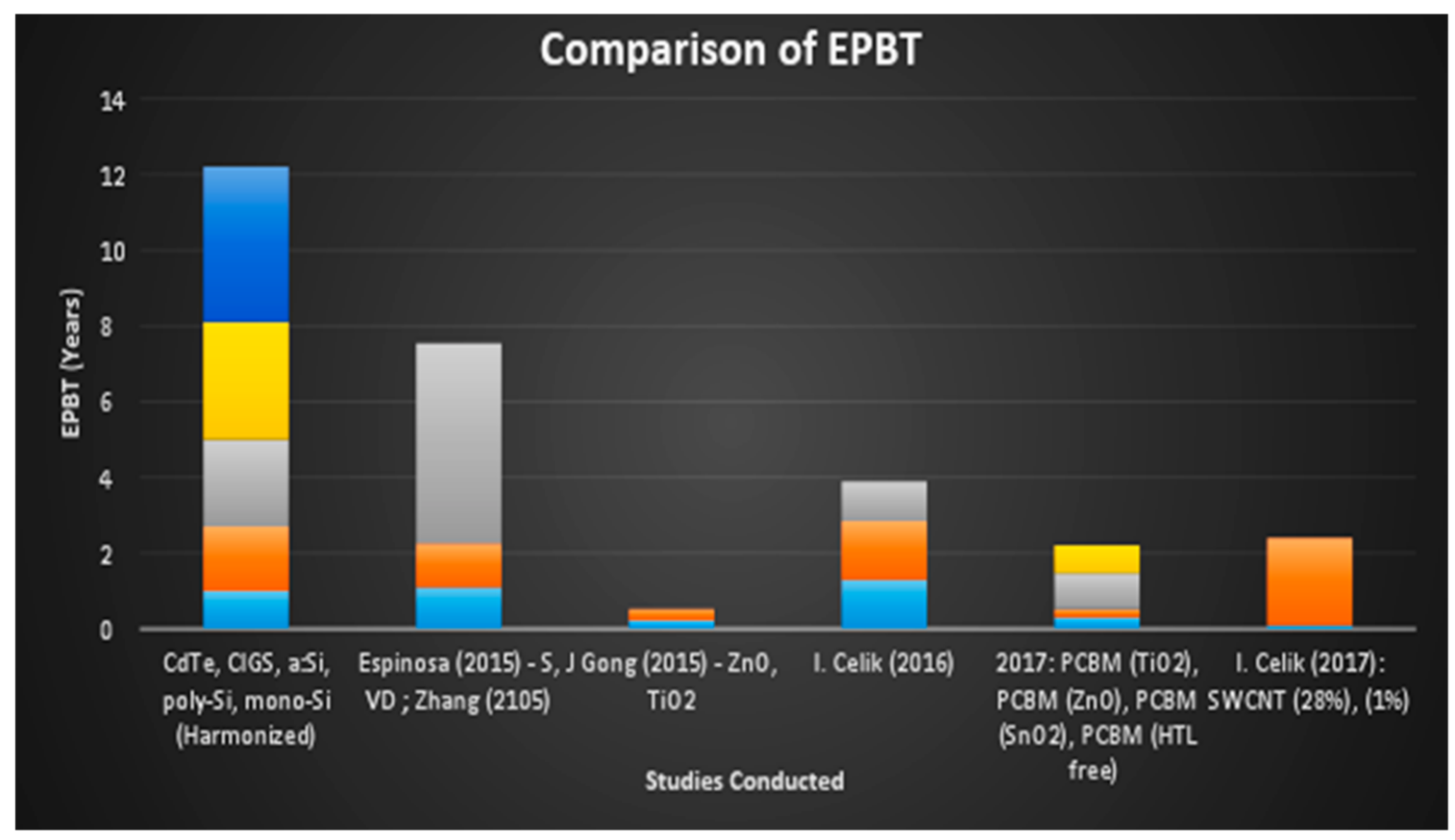

Figure 7. Comparison of the EPBT of different solar cells. Calculations have been done over time and the studies have been collected here. The figure shows the clear difference in EPBT based on materials used and calculation methods. 


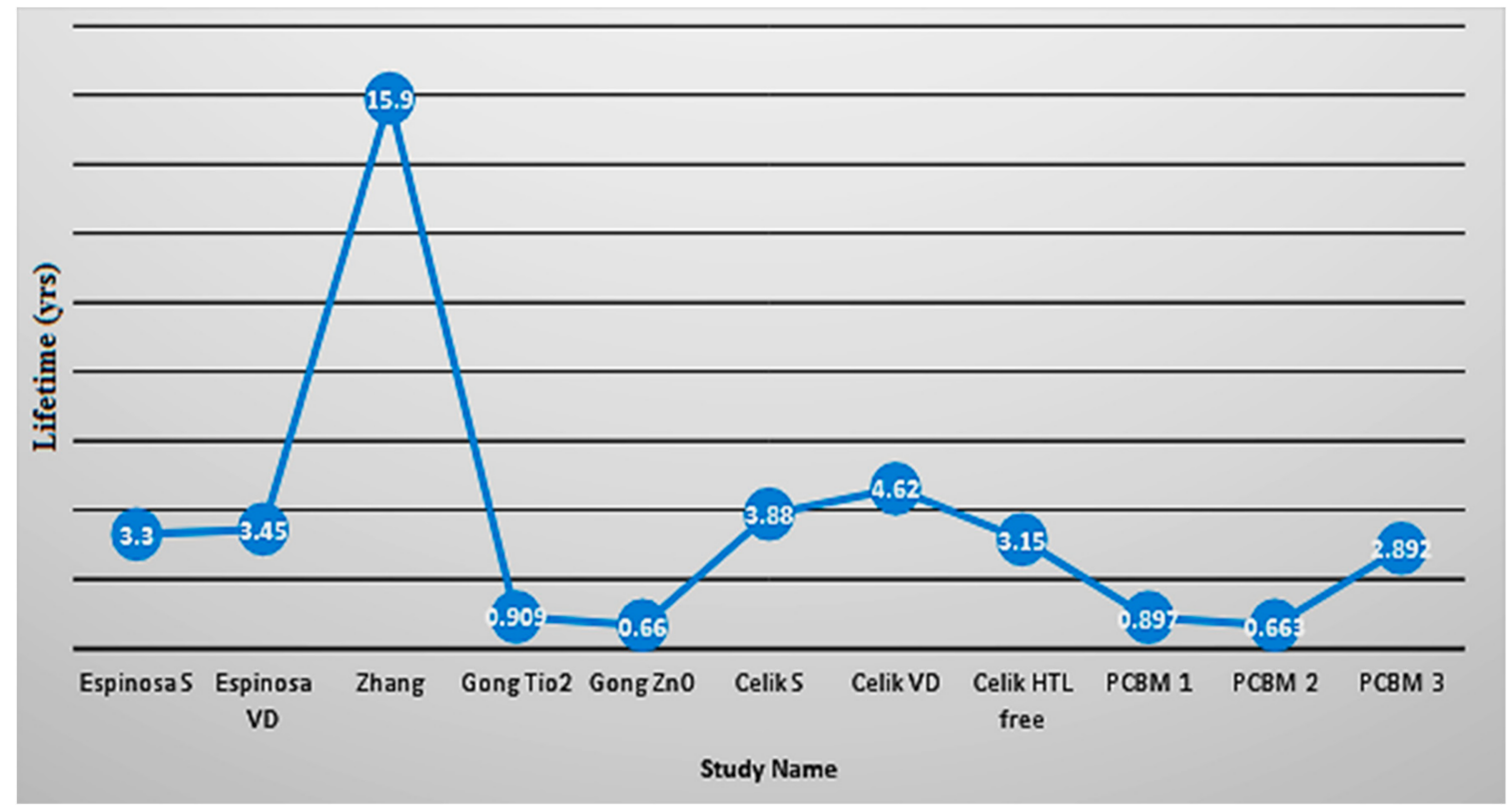

Figure 8. A look at the viability of commercial solar cells. Figure 7 provides a reference.

\subsection{Global Consideration of EPBT}

Apart from the architecture of the cell, the energy embedded in the manufacturing of materials is another important consideration in the solar insolation, which affects the EPBT. Thus far, most of the above studies have taken the average of $1700 \mathrm{KWh} / \mathrm{m}^{2} /$ year, except for Gong who took $1960 \mathrm{KWh} / \mathrm{m}^{2} /$ year to consider areas in the United States which get more heat. However, for emerging energy markets, especially in terms of competition, perhaps India and China need to be considered separately [223-226].

Consider south, central, and west India for example. The daily average for these places (including major states of Kerala, Karnataka, Madhya Pradesh, and especially Rajasthan) is greater than $5 \mathrm{KWh} / \mathrm{m}^{2} /$ year as shown in the Figure 9 . This translates to more than $1825 \mathrm{KWh} / \mathrm{m}^{2} /$ year of solar insolation in such places on average.

About $1,400,000 \mathrm{~km}^{2}$ of land is available with an annual solar insolation of $5-5.5 \mathrm{KWh} / \mathrm{m}^{2} /$ day which is around $1825-2007 \mathrm{KWh} / \mathrm{m}^{2} /$ year, while $650,000 \mathrm{~km}^{2}$ has a solar insolation of 5.5-6 KWh $/ \mathrm{m}^{2} /$ day translating into $2007-2190 \mathrm{KWh} / \mathrm{m}^{2} /$ year, and this rounds up to $2,000,000 \mathrm{~km}^{2}$ of area (62.5\% of total Indian area) that is available. Considering that $10 \%$ of the land is utilised, solar PV systems installation with perovskite solar cells ( $\mathrm{PCE}=15 \%$ and performance ratio of $75 \%$; a conservative estimate), solar insolation average of $1970 \mathrm{KWh} / \mathrm{m}^{2} /$ year, and assuming the conversion factor (mentioned above) of India to also be 0.35 , we arrive at:

$$
\text { Energy Produced }\left(\frac{\mathrm{KWh}}{\mathrm{Year}}\right)=\frac{1970 \times 0.15 \times 0.75}{0.35} \times 200,000
$$

which is $1266.4 \times 10^{5} \mathrm{KWh}$ /year, or $4.55 \times 10^{14} \mathrm{MJ} /$ year. That is $455 \mathrm{TJ}$ of energy per year, giving roughly $0.000035 \mathrm{GJ}$ of the per capita energy, or $0.0015 \%$ of the total per capita energy consumption of India (22.042 GJ) [227] and $0.0086 \%$ of the per capita electrical energy consumption (1122 KWh) [228]. With such a low EPBT and manufacturing time, perovskite solar cells provide a much-needed cost effective and energy intensive solution to the problem of solar energy. 


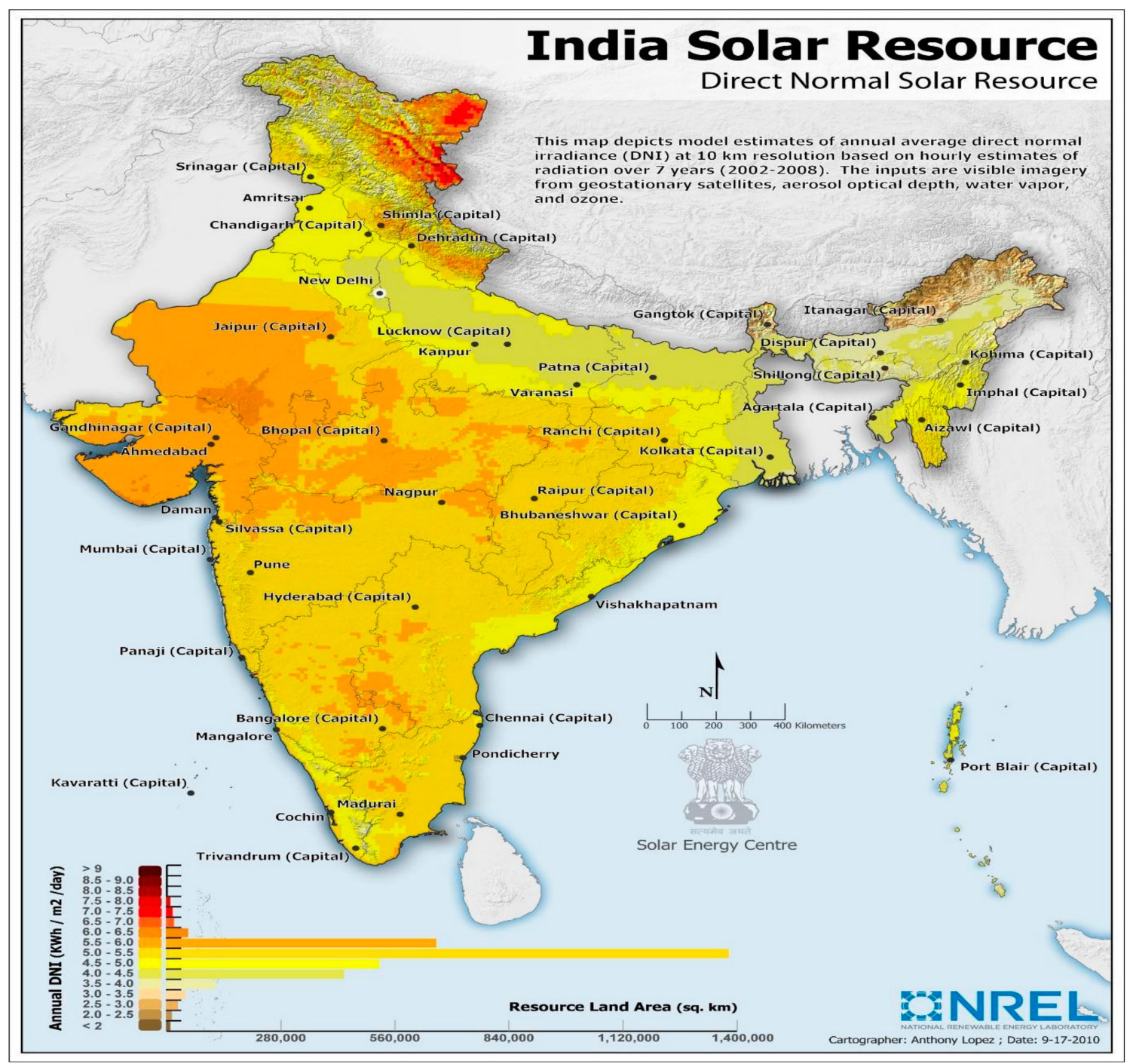

Figure 9. Amount of solar insolation in India on average showing areas of extreme heat which may be considered in the calculations of energy payback time. (Taken from NREL solar radiation database).

\section{Perovskite versus the Rest}

It is safe to assume that the only competition PSCs will face in the future is from the very technology it is trying to overtake. To achieve the level of success silicon based solar cells have achieved, PSCs first need to achieve a stability of at least a few years (2-5). However, thus far, such a goal seems rather far off considering that this stability threshold has not been reached by laboratory cells yet. A low stability device not only affects the efficiency of the solar cell but also increases the cost since cell modules must be replaced, thus requiring human resources and cost for instalment of modules in a commercial setting.

When it comes to efficiency, PSCs are on their way to match Silicon solar cells and other alternatives. Lab based cells $\left(1 \mathrm{~cm}^{2}\right)$ should soon reach efficiency records of Silicon based cells. While cell modules $\left(>1 \mathrm{~m}^{2}\right)$ are far from such an efficiency limit, an efficiency threshold of $15-20 \%$ can be considered viable. Obviously, a higher efficiency level is desired, but even within such a range, perovskites will outdo silicon cells in terms of energy to cost ratio.

Lastly, the one area where PSCs can be said to have overtaken silicon cells is the cost of fabrication (and the low energy requirement). This can be said to be the primary motivator of research in the field. However, much can still be done about the cost in the case of PSCs, especially about components such 
as electrodes and HTM. While Silicon cells have achieved their most desirable configuration, PSCs still require further research.

Therefore, to outdo silicon-based cells, a conservative estimate of a $1 \mathrm{~m}^{2}$ PSC module can be predicted as:

- Stability: 3 years (with the cell retaining at least $95-99 \%$ of its original efficiency)

- Efficiency: $15 \%$

- Cost of Fabrication: 1300-1500 USD

\section{Conclusions}

In this review article, we have presented the state of perovskite solar cells over the past few years. In being comprehensive, we have studied the problems present within different aspects associated with the cells, namely stability, efficiency, and cost of fabrication/energy of fabrication, and have also provided a detailed review of the research (both past and ongoing) which has been done to evolve the state of perovskite solar cells to the next level. If PSCs were to be thought of as caterpillars in the year 2013 , now, it is safe to say that they are undergoing a metamorphosis; they are in the developmental state known as a chrysalis.

We have shown the achievements of the past few years, the problems overcome, and new challenges which have yet to be conquered, keeping not just a scientific mindset but also an economical and therefore a competitive mindset with respect to silicon solar cells.

PSCs have reached efficiencies greater than $22 \%$, which is an exponential increase considering they started at a meagre $4 \%$. Research to increase the efficiency has focused on the film quality, hole and electron transport layers which form the second most important parts of the cell, the electrodes used, and even tandem solar cells which utilize either two PSCs or a perovskite coupled with a silicon cell or other alternatives. The use of tandems is one to look out for, especially since tandems often utilise a greater spectrum of the sunlight, thereby having a much higher efficiency. Research has also been focused in areas utilising more than two components of the cell, which include the interaction of HTM/ETM and perovskite layers; utilising buffer layers to increase the overall efficiency.

Following efficiency, the most important aspect of the solar cells is stability. As we have reported, this is also the aspect which must be researched the most if PSCs are to compete in the market. The research in this area has been focused on the interaction of PSCs with the environment which leads to a decay of the layers. The cells fair badly with moisture, heat, and sunlight itself. Methods to counter this include utilisation of buffer layers, changing the materials of the perovskite cells to those which do not decay, and better techniques of encapsulation. Future research needs to strive for both longer stability times with high efficiency (for lab cells) and a higher stability for bigger albeit low efficiency modules.

The third significant factor is the cost of fabrication, in terms of both cost of materials and energy utilised, and it also forms a good measuring factor for the PSCs based on EPBT and EROI calculations. Here, we have also collected data and added a bit of our own to show that PSCs (assuming they reach a required level of stability and efficiency) will outdo silicon cells when it comes to energy and cost requirements. Perovskite solar cells are possibly the only technology which gives a much faster payback than Silicon cells while also being the easiest to fabricate. Finally, extending the scope of EPBT measurements, we have included a small section that talks about the use of PSCs in areas other than the USA and Europe, focusing on India and China, although we have stayed away from the geo-political conditions which often accompany the spread of any new technology.

In conclusion, the research which has been ongoing for the past five years has achieved significant results. However, if PSCs need to move out from the confines of labs into the sunlit world, especially in an era dominated by energy, the research needs to accelerate further. With the emergence of private companies vying for the future market, it appears perovskites should soon be everywhere; however, practically, that moment is probably far away. To answer the question of the 
future, this will suffice for now: theoretically, perovskites are already a star; practically, they have yet to leave the womb.

Author Contributions: A.B. wrote the first draft of the paper (including EPBT studies) with contribution from G.R. B.P.D., P.C., and T.B.K. provided major inputs in efficiency and stability studies along with fact-checking the rest of paper. Their contributions gave depth and made the paper more comprehensive. S.K.P. oversaw and guided the entire study, structuring and editing the paper and providing the rest with resources when necessary.

Conflicts of Interest: The authors declare no conflict of interest.

\section{References}

1. Yang, W.S.; Park, B.W.; Jung, E.H.; Jeon, N.J.; Kim, Y.C.; Lee, D.U.; Shin, S.S.; Jangwon, S.; Kim, E.K.; Noh, J.H.; et al. Iodide management in formamidinium-lead-halide-based perovskite layers for efficient solar cells. Science 2017, 356, 1376-1379. [CrossRef] [PubMed]

2. Burschka, J.; Pellet, N.; Moon, S.-J.; Humphry-Baker, R.; Gao, P.; Nazeeruddin, M.K.; Grätzel, M. Sequential Deposition as a Route to High-Performance Perovskite-Sensitized Solar Cells. Nature 2013, 499, 316. [CrossRef] [PubMed]

3. Im, J.-H.; Lee, C.-R.; Lee, J.-W.; Park, S.-W.; Park, N.-G. 6.5\% Efficient Perovskite Quantum-Dot-Sensitized Solar Cell. Nanoscale 2011, 3, 4088-4093. [CrossRef] [PubMed]

4. Bush, K.A.; Palmstrom, A.F.; Yu, Z.J.; Boccard, M.; Rongrong Cheacharoen, J.P.M.; McMeekin, D.P.; Hoye, R.L.Z.; Bailie, C.D.; Leijtens, T.; Peters, I.M.; et al. 23.6\%-Efficient Monolithic Perovskite/Silicon Tandem Solar Cells with Improved Stability. Nat. Energy 2017, 2, 17009. [CrossRef]

5. Masuko, K.; Shigematsu, M.; Hashiguchi, T.; Fujishima, D.; Kai, M.; Yoshimura, N.; Yamaguchi, T.; Ichihashi, Y.; Mishima, T.; Matsubara, N.; et al. Achievement of More Than 25\% Conversion Efficiency with Crystalline Silicon Heterojunction Solar Cell. IEEE J. Photovolt. 2014, 4, 1433-1435. [CrossRef]

6. Taguchi, M.; Yano, A.; Tohoda, S.; Matsuyama, K.; Nakamura, Y.; Nishiwaki, T.; Fujita, K.; Maruyama, E. 24.7\% Record Efficiency HIT Solar Cell on Thin Silicon Wafer. IEEE J. Photovolt. 2014, 4, 96-99. [CrossRef]

7. Savin, H.; Repo, P.; von Gastrow, G.; Ortega, P.; Calle, E.; Garín, M.; Alcubilla, R. Black Silicon Solar Cells with Interdigitated Back-Contacts Achieve 22.1\% Efficiency. Nat. Nanotechnol. 2015, 10, 624. [CrossRef] [PubMed]

8. Ma, S.; Zhang, H.; Zhao, N.; Cheng, Y.; Wang, M.; Shen, Y.; Tu, G. Spiro-Thiophene Derivatives as Hole-Transport Materials for Perovskite Solar Cells. J. Mater. Chem. A 2015, 3, 12139-12144. [CrossRef]

9. Zheng, L.; Ma, Y.; Chu, S.; Wang, S.; Qu, B.; Xiao, L.; Chen, Z.; Gong, Q.; Wu, Z.; Hou, X. Improved Light Absorption and Charge Transport for Perovskite Solar Cells with Rough Interfaces by Sequential Deposition. Nanoscale 2014, 6, 8171-8176. [CrossRef] [PubMed]

10. Sum, T.C.; Mathews, N. Advancements in Perovskite Solar Cells: Photophysics behind the Photovoltaics. Energy Environ. Sci. 2014, 7, 2518-2534. [CrossRef]

11. Xing, G.; Mathews, N.; Sun, S.; Lim, S.S.; Lam, Y.M.; Grätzel, M.; Mhaisalkar, S.; Sum, T.C. Long-Range Balanced Electron- and Hole-Transport Lengths in Organic-Inorganic $\mathrm{CH}_{3} \mathrm{NH}_{3} \mathrm{PbI}_{3}$. Science 2013, 342, 344-347. [CrossRef] [PubMed]

12. Stoumpos, C.C.; Malliakas, C.D.; Kanatzidis, M.G. Semiconducting Tin and Lead Iodide Perovskites with Organic Cations: Phase Transitions, High Mobilities, and Near-Infrared Photoluminescent Properties. Inorg. Chem. 2013, 52, 9019-9038. [CrossRef] [PubMed]

13. Leyden, M.R.; Ono, L.K.; Raga, S.R.; Kato, Y.; Wang, S.; Qi, Y. High Performance Perovskite Solar Cells by Hybrid Chemical Vapor Deposition. J. Mater. Chem. A 2014, 2, 18742-18745. [CrossRef]

14. Zardetto, V.; Williams, B.L.; Perrotta, A.; Di Giacomo, F.; Verheijen, M.A.; Andriessen, R.; Creatore, M. Atomic layer deposition for perovskite solar cells: Research status, opportunities and challenges. Sustain. Energy Fuels 2017, 1, 30-55. [CrossRef]

15. Wang, K.; Zhao, W.; Liu, J.; Niu, J.; Liu, Y.; Ren, X.; Feng, J.; Liu, Z.; Sun, J.; Wang, D.; et al. CO 2 Plasma-Treated $\mathrm{TiO}_{2}$ Film as an Effective Electron Transport Layer for High-Performance Planar Perovskite Solar Cells. ACS Appl. Mater. Interfaces 2017, 9, 33989-33996. [CrossRef] [PubMed]

16. Shockley, W.; Quiesser, H.J. Detailed Balance Limit of Efficiency of $p$ - $n$ Junction Solar Cells. J. Appl. Phys. 1961, 32, 510. [CrossRef] 
17. Sha, W.E.I.; Ren, X.; Chen, L.; Choy, W.C.H. The Efficiency Limit of $\mathrm{CH}_{3} \mathrm{NH}_{3} \mathrm{PbI}_{3}$ Perovskite Solar Cells. Appl. Phys. Lett. 2015, 106, 221104. [CrossRef]

18. Nayak, P.K.; Cahen, D. Updated Assessment of Possibilities and Limits for Solar Cells. Adv. Mater. 2013, 26, 1622-1628. [CrossRef] [PubMed]

19. Yoshida, K.S.; Furube, A.; Yoshida, Y. Theoretical Limit of Power Conversion Efficiency for Organic and Hybrid Halide Perovskite Photovoltaics. Jpn. J. Appl. Phys. 2015, 54, 08 KF04.

20. Grånäs, O.; Vinichenko, D.; Kaxiras, E. Establishing the Limits of Efficiency of Perovskite Solar Cells from First Principles Modeling. Sci. Rep. 2016, 6, 36108. [CrossRef] [PubMed]

21. Sha, W.E.I.; Zhang, H.; Wang, Z.S.; Zhu, H.L.; Ren, X.G.; Lin, F.; Jen, A.K.-Y.; Choy, W.C.H. Quantifying Efficiency Loss of Perovskite Solar Cells by a Modified Detailed Balance Model. Adv. Energy Mater. 2017, 8, 1701586. [CrossRef]

22. Crossland, E.J.W.; Noel, N.; Sivaram, V.; Leijtens, T.; Alexander-Webber, J.A.; Snaith, H.J. Mesoporous TiO Single Crystals Delivering Enhanced Mobility and Optoelectronic Device Performance. Nature 2013, 495, 215-219. [CrossRef] [PubMed]

23. Miller, O.D.; Yablonovitch, E.; Kurtz, S.R. Strong Internal and External Luminescence as Solar Cells Approach the Shockley-Queisser Limit. IEEE J. Photovolt. 2012, 2, 303-311. [CrossRef]

24. Zhang, W.; Saliba, M.; Moore, D.T.; Pathak, S.K.; Hörantner, M.T.; Stergiopoulos, T.; Stranks, S.D.; Eperon, G.E.; Alexander-Webber, J.A.; Abate, A.; et al. Ultrasmooth Organic-Inorganic Perovskite Thin-Film Formation and Crystallization for Efficient Planar Heterojunction Solar Cells. Nat. Commun. 2015, 6, 6142. [CrossRef] [PubMed]

25. Nie, W.; Tsai, H.; Asadpour, R.; Blancon, J.-C.; Neukirch, A.J.; Gupta, G.; Crochet, J.J.; Chhowalla, M.; Tretiak, S.; Alam, M.A.; et al. High-Efficiency Solution-Processed Perovskite Solar Cells with Millimeter-Scale Grains. Science 2015, 347, 522-525. [CrossRef] [PubMed]

26. Saliba, M.; Matsui, T.; Domanski, K.; Seo, J.-Y.; Ummadisingu, A.; Zakeeruddin, S.M.; Correa-Baena, J.-P.; Tress, W.R.; Abate, A.; Hagfeldt, A.; et al. Incorporation of Rubidium Cations into Perovskite Solar Cells Improves Photovoltaic Performance. Science 2016, 354, 206. [CrossRef] [PubMed]

27. Yun, J.; Jun, J.; Yu, H.; Lee, K.; Ryu, J.; Lee, J.; Jang, J. Highly Efficient Perovskite Solar Cells Incorporating NiO Nanotubes: Increased Grain Size and Enhanced Charge Extraction. J. Mater. Chem. A 2017, 5, 21750-21756. [CrossRef]

28. Wu, Y.; Xie, F.; Chen, H.; Yang, X.; Su, H.; Cai, M.; Zhou, Z.; Noda, T.; Han, L. Thermally Stable MAPbI 3 Perovskite Solar Cells with Efficiency of $19.19 \%$ and Area over $1 \mathrm{~cm}^{2}$ Achieved by Additive Engineering. Adv. Mater. 2017, 29, 1701073. [CrossRef] [PubMed]

29. Bai, Y.; Dong, Q.; Shao, Y.; Deng, Y.; Wang, Q.; Shen, L.; Wang, D.; Wei, W.; Huang, J. Enhancing Stability and Efficiency of Perovskite Solar Cells with Crosslinkable Silane-Functionalized and Doped Fullerene. Nat. Commun. 2016, 7, 12806. [CrossRef] [PubMed]

30. Zhou, H.P.; Chen, Q.; Li, G.; Luo, S.; Song, T.B.; Duan, H.-S.S.; Hong, Z.R.; You, J.B.; Liu, Y.S.; Yang, Y. Interface Engineering of Highly Efficient Perovskite Solar Cells. Science 2014, 345, 542-546. [CrossRef] [PubMed]

31. Yang, M.; Zhang, T.; Schulz, P.; Li, Z.; Li, G.; Kim, D.H.; Guo, N.; Berry, J.J.; Zhu, K.; Zhao, Y. Facile Fabrication of Large-Grain $\mathrm{CH}_{3} \mathrm{NH}_{3} \mathrm{PbI}_{3-x} \mathrm{Br}_{\mathrm{x}}$ Films for High-Efficiency Solar Cells via $\mathrm{CH}_{3} \mathrm{NH}_{3} \mathrm{Br}$-Selective Ostwald Ripening. Nat. Commun. 2016, 7, 12305. [CrossRef] [PubMed]

32. Uribe, J.I.; Ciro, J.; Montoya, J.F.; Osorio, J.; Jaramillo, F. Enhancement of Morphological and Optoelectronic Properties of Perovskite Films by $\mathrm{CH}_{3} \mathrm{NH}_{3} \mathrm{Cl}$ Treatment for Efficient Solar Minimodules. ACS Appl. Energy Mater. 2018, 1, 1047-1052. [CrossRef]

33. Conings, B.; Bretschneider, S.A.; Babayigit, A.; Gauquelin, N.; Cardinaletti, I.; Manca, J.V.; Verbeeck, J.; Snaith, H.J.; Boyen, H.-G. Structure-Property Relations of Methylamine Vapor Treated Hybrid Perovskite $\mathrm{CH}_{3} \mathrm{NH}_{3} \mathrm{PbI}_{3}$ Films and Solar Cells. ACS Appl. Mater. Interfaces 2017, 9, 8092-8099. [CrossRef] [PubMed]

34. Liu, Z.; He, T.; Liu, K.; Zhi, Q.; Yuan, M. Solution Processed Double-Decked $\mathrm{V}_{2} \mathrm{O}_{\mathrm{x}} /$ PEDOT:PSS Film Serves as the Hole Transport Layer of an Inverted Planar Perovskite Solar Cell with High Performance. RSC Adv. 2017, 7, 26202-26210. [CrossRef]

35. Wu, J.; Xu, X.; Zhao, Y.; Shi, J.; Xu, Y.; Luo, Y.; Li, D.; Wu, H.; Meng, Q. DMF as an Additive in a Two-Step Spin-Coating Method for 20\% Conversion Efficiency in Perovskite Solar Cells. ACS Appl. Mater. Interfaces 2017, 9, 26937-26947. [CrossRef] [PubMed] 
36. Zhang, X.; Ji, G.; Xiong, D.; Su, Z.; Zhao, B.; Shen, K.; Yang, Y.; Gao, X. Graphene Oxide as an Additive to Improve Perovskite Film Crystallization and Morphology for High-Efficiency Solar Cells. RSC Adv. 2018, 8, 987-993. [CrossRef]

37. Faraji, N.; Qin, C.; Matsushima, T.; Adachi, C.; Seidel, J. Grain Boundary Engineering of Halide Perovskite $\mathrm{CH}_{3} \mathrm{NH}_{3} \mathrm{PbI}_{3}$ Solar Cells with Photochemically-Active Additives. J. Phys. Chem. C 2018, 122, 4817-4821. [CrossRef]

38. Xie, L.; Cho, A.-N.; Park, N.-G.; Kim, K. Efficient and Reproducible $\mathrm{CH}_{3} \mathrm{NH}_{3} \mathrm{PbI}_{3}$ Perovskite Layer Prepared Using a Binary Solvent Containing a Cyclic Urea Additive. ACS Appl. Mater. Interfaces 2018, 10, 9390-9397. [CrossRef] [PubMed]

39. Wang, J.-F.; Zhu, L.; Zhao, B.-G.; Zhao, Y.-L.; Song, J.; Gu, X.-Q.; Qiang, Y.-H. Surface Engineering of Perovskite Films for Efficient Solar Cells. Sci. Rep. 2017, 7, 14478. [CrossRef] [PubMed]

40. Zhang, W.; Pathak, S.; Sakai, N.; Stergiopoulos, T.; Nayak, P.K.; Noel, N.K.; Haghighirad, A.A.; Burlakov, V.M.; deQuilettes, D.W.; Sadhanala, A.; et al. Enhanced Optoelectronic Quality of Perovskite Thin Films with Hypophosphorous Acid for Planar Heterojunction Solar Cells. Nat. Commun. 2015, 6, 10030. [CrossRef] [PubMed]

41. Noel, N.K.; Abate, A.; Stranks, S.D.; Parrott, E.S.; Burlakov, V.M.; Goriely, A.; Snaith, H.J. Enhanced Photoluminescence and Solar Cell Performance via Lewis Base Passivation of Organic-Inorganic Lead Halide Perovskites. ACS Nano 2014, 8, 9815-9821. [CrossRef] [PubMed]

42. Wang, J.T.-W.; Wang, Z.; Pathak, S.; Zhang, W.; deQuilettes, D.W.; Wisnivesky-Rocca-Rivarola, F.; Huang, J.; Nayak, P.K.; Patel, J.B.; Mohd Yusof, H.A.; et al. Efficient Perovskite Solar Cells by Metal Ion Doping. Energy Environ. Sci. 2016, 9, 2892-2901. [CrossRef]

43. Zhao, W.; Yao, Z.; Yu, F.; Yang, D.; Liu, S.F. Alkali Metal Doping for Improved $\mathrm{CH}_{3} \mathrm{NH}_{3} \mathrm{PbI}_{3}$ Perovskite Solar Cells. Adv. Sci. 2018, 5, 1700131. [CrossRef] [PubMed]

44. Zhao, T.; Chueh, C.-C.; Chen, Q.; Rajagopal, A.; Jen, A.K.-Y. Defect Passivation of Organic-Inorganic Hybrid Perovskites by Diammonium Iodide toward High-Performance Photovoltaic Devices. ACS Energy Lett. 2016, 1, 757-763. [CrossRef]

45. Xu, M.; Feng, J.; Ou, X.L.; Zhang, Z.Y.; Zhang, Y.F.; Wang, H.Y.; Sun, H.B. Surface Passivation of Perovskite Film by Small Molecule Infiltration for Improved Efficiency of Perovskite Solar Cells. IEEE Photonics J. 2016, 8, 1-7. [CrossRef]

46. Jamaludin, N.F.; Yantara, N.; Ng, Y.F.; Li, M.; Goh, T.W.; Thirumal, K.; Sum, T.C.; Mathews, N.; Soci, C.; Mhaisalkar, S. Grain Size Modulation and Interfacial Engineering of $\mathrm{CH}_{3} \mathrm{NH}_{3} \mathrm{PbBr}_{3}$ Emitter Films through Incorporation of Tetraethylammonium Bromide. ChemPhysChem 2018, 19, 1075. [CrossRef] [PubMed]

47. Jiang, L.L.; Wang, Z.K.; Li, M.; Zhang, C.C.; Ye, Q.Q.; Hu, K.H.; Lu, D.Z.; Fang, P.F.; Liao, L.S. Passivated Perovskite Crystallisation via g- $\mathrm{C}_{3} \mathrm{~N}_{4}$ for High-Performance Solar Cells. Adv. Funct. Mater. 2018, 28, 1705875. [CrossRef]

48. Seo, J.; Park, S.; Kim, Y.C.; Jeon, N.J.; Noh, J.H.; Yoon, S.C.; Seok, S.I. Benefits of Very Thin PCBM and LiF Layers for Solution-Processed p-i-n Perovskite Solar Cells. Energy Environ. Sci. 2014, 7, 2642-2646. [CrossRef]

49. Jeon, N.J.; Lee, H.G.; Kim, Y.C.; Seo, J.; Noh, J.H.; Lee, J.; Seok, S.I. O-Methoxy Substituents in Spiro-OMeTAD for Efficient Inorganic-Organic Hybrid Perovskite Solar Cells. J. Am. Chem. Soc. 2014, 136, 7837-7840. [CrossRef] [PubMed]

50. Shi, D.; Qin, X.; Li, Y.; He, Y.; Zhong, C.; Pan, J.; Dong, H.; Xu, W.; Li, T.; Hu, W.; et al. Spiro-OMeTAD Single Crystals: Remarkably Enhanced Charge-Carrier Transport via Mesoscale Ordering. Sci. Adv. 2016, 2, e1501491. [CrossRef] [PubMed]

51. Cho, K.T.; Paek, S.; Grancini, G.; Roldan-Carmona, C.; Gao, P.; Lee, Y.; Nazeeruddin, M.K. Highly Efficient Perovskite Solar Cells with a Compositionally Engineered Perovskite/Hole Transporting Material Interface. Energy Environ. Sci. 2017, 10, 621-627. [CrossRef]

52. Yu, J.C.; Hong, J.A.; Jung, E.D.; Kim, D.B.; Baek, S.-M.; Lee, S.; Song, M.H. Highly efficient and stable inverted perovskite solar cell employing PEDOT:GO composite layer as a hole transport layer. Sci. Rep. 2018, 8, 1070. [CrossRef] [PubMed]

53. Seo, S.; Park, I.J.; Kim, M.; Lee, S.; Bae, C.; Jung, H.S.; Shin, H. An ultra-thin, un-doped NiO hole transporting layer of highly efficient $(16.4 \%)$ organic-inorganic hybrid perovskite solar cells. Nanoscale 2016, 8, 11403-11412. [CrossRef] [PubMed] 
54. Park, I.J.; Kang, G.; Park, M.A.; Kim, J.S.; Seo, S.W.; Kim, D.H.; Zhu, K.; Park, T.; Kim, J.Y. Highly Efficient and Uniform $1 \mathrm{~cm}^{2}$ Perovskite Solar Cells with an Electrochemically Deposited $\mathrm{NiO}_{\mathrm{x}}$ Hole-Extraction Layer. ChemSusChem 2017, 10, 2660-2667. [CrossRef] [PubMed]

55. Chen, W.; Liu, F.Z.; Feng, X.Y.; Djurišić, A.B.; Chan, W.K.; He, Z.B. Cesium Doped $\mathrm{NiO}_{\mathrm{x}}$ as an Efficient Hole Extraction Layer for Inverted Planar Perovskite Solar Cells. Adv. Energy Mater. 2017, 7, 1700722. [CrossRef]

56. Huang, A.B.; Zhu, J.T.; Zheng, J.Y.; Yu, Y.; Liu, Y.; Yang, S.W.; Bao, S.H.; Lei, L.; Jin, P. Achieving High-Performance Planar Perovskite Solar Cells with Co-Sputtered Co-Doping $\mathrm{NiO}_{\mathrm{x}}$ Hole Transport Layers by Efficient Extraction and Enhanced Mobility. J. Mater. Chem. C 2016, 4, 10839-10846. [CrossRef]

57. Liu, M.H.; Zhou, Z.J.; Zhang, P.P.; Tian, Q.W.; Zhou, W.H.; Kou, D.X.; Wu, S.X. p-type Li, Cu-codoped NiO hole-transporting layer for efficient planar perovskite solar cells. Opt. Express 2016, 24, 128-132. [CrossRef] [PubMed]

58. Kim, J.H.; Liang, P.W.; Williams, S.T.; Cho, N.; Chueh, C.C.; Glaz, M.S.; Ginger, D.S.; Jen, A.K.Y. High-Performance and Environmentally Stable Planar Heterojunction Perovskite Solar Cells Based on a Solution-Processed Copper-Doped Nickel Oxide Hole-Transporting Layer. Adv. Mater. 2015, 27, 695-701. [CrossRef] [PubMed]

59. Zheng, J.; Hu, L.; Yun, J.S.; Zhang, M.; Lau, C.-F.J.; Bing, J.; Deng, X.; Ma, Q.; Cho, Y.; Fu, W.-F.; et al. Solution-Processed, Silver-Doped NiOx as Hole Transporting Layer for High Efficiency Inverted Perovskite Solar Cells. ACS Appl. Energy Mater. 2018, 1, 561-570. [CrossRef]

60. Zhao, D.; Sexton, M.; Park, H.-Y.; Baure, G.; Nino, J.C.; So, F. High-Efficiency Solution-Processed Planar Perovskite Solar Cells with a Polymer Hole Transport Layer. Adv. Energy Mater. 2015, 5, 1401855. [CrossRef]

61. Xu, B.; Bi, D.; Hua, Y.; Liu, P.; Cheng, M.; Gratzel, M.; Sun, L. A low-cost spiro[fluorene-9,9'-xanthene]-based hole transport material for highly efficient solid-state dye-sensitized solar cells and perovskite solar cells. Energy Environ. Sci. 2016, 9, 873-877. [CrossRef]

62. Li, H.; Fu, K.; Hagfeldt, A.; Grätzel, M.; Mhaisalkar, S.G.; Grimsdale, A.C. A simple 3,4-ethylenedioxythiophene based hole-transporting material for perovskite solar cells. Chem.-Int. Ed. 2014, 53, 4085-4088. [CrossRef] [PubMed]

63. Rakstys, K.; Abate, A.; Dar, M.I.; Gao, P.; Jankauskas, V.; Jacopin, G.; Kamarauskas, E.; Kazim, S.; Ahmad, S.; Grätzel, M.; et al. Triazatruxene-Based Hole Transporting Materials for Highly Efficient Perovskite Solar Cells. J. Am. Chem. Soc. 2015, 137, 16172-16178. [CrossRef] [PubMed]

64. Heo, J.H.; Im, S.H.; Noh, J.H.; Mandal, T.N.; Lim, C.-S.; Chang, J.A.; Lee, Y.H.; Kim, H.J.; Sarkar, A.; Nazeeruddin, M.K.; et al. Efficient inorganic-organic hybrid heterojunction solar cells containing perovskite compound and polymeric hole conductors. Nat. Photon. 2013, 7, 486-491. [CrossRef]

65. Jiang, X.; Yu, Z.; Zhang, Y.; Lai, J.; Li, J.; Gurzadyan, G.G.; Sun, L. High-Performance Regular Perovskite Solar Cells Employing Low-Cost Poly (ethylenedioxythiophene) as a Hole-Transporting Material. Sci. Rep. 2017, 7, 42564. [CrossRef] [PubMed]

66. Wang, Y.; Su, T.-S.; Tsai, H.-Y.; Wei, T.-C.; Chi, Y. Spiro-Phenylpyrazole/Fluorene as Hole-Transporting Material for Perovskite Solar Cells. Sci. Rep. 2017, 7, 7859. [CrossRef] [PubMed]

67. Choi, H.; Mai, C.-K.; Kim, H.-B.; Jeong, J.; Song, S.; Bazan, G.C.; Heeger, A.J. Conjugated polyelectrolyte hole transport layer for inverted-type perovskite solar cells. Nat. Commun. 2015, 6, 7348. [CrossRef] [PubMed]

68. Chen, H.-W.; Huang, T.-Y.; Chang, T.-H.; Sanehira, Y.; Kung, C.-W.; Chu, C.-W.; Ikegami, M.; Miyasaka, T.; Ho, K.-C. Efficiency Enhancement of Hybrid Perovskite Solar Cells with MEH-PPV Hole-Transporting Layers. Sci. Rep. 2016, 6, 34319. [CrossRef] [PubMed]

69. Pathak, S.K.; Abate, A.; Ruckdeschel, P.; Roose, B.; Gödel, K.C.; Vaynzof, Y.; Santhala, A.; Watanabe, S.; Hollman, D.J.; Noel, N.; et al. Performance and Stability Enhancement of Dye-Sensitized and Perovskite Solar Cells by Al Doping of $\mathrm{TiO}_{2}$. Adv. Funct. Mater. 2014, 24, 6046-6055. [CrossRef]

70. Chen, B.X.; Rao, H.-S.; Li, W.-G.; Xu, Y.-F.; Chen, H.-Y.; Kuang, D.-B.; Su, C.-Y. Achieving high-performance planar perovskite solar cell with $\mathrm{Nb}$-doped $\mathrm{TiO}_{2}$ compact layer by enhanced electron injection and efficient charge extraction. J. Mater. Chem. A 2016, 4, 5647-5653. [CrossRef]

71. Giordano, F.; Abate, A.; Correa Baena, J.P.; Saliba, M.; Matsui, T.; Im, S.H.; Graetzel, M. Enhanced electronic properties in mesoporous $\mathrm{TiO}_{2}$ via lithium doping for high-efficiency perovskite solar cells. Nat. Commun. 2016, 7, 10379. [CrossRef] [PubMed] 
72. Peng, J.; Duong, T.; Zhou, X.; Shen, H.; Wu, Y.; Mulmudi, H.K.; Wan, Y.; Zhong, D.; Li, J.; Tsuzuki, T.; et al. Efficient Indium-Doped $\mathrm{TiO}_{\mathrm{x}}$ Electron Transport Layers for High Performance Perovskite Solar Cells and Perovskite-Silicon Tandems. Adv. Energy Mater. 2017, 7, 1601768. [CrossRef]

73. Gu, X.; Wang, Y.; Zhang, T.; Liu, D.; Zhang, R.; Zhang, P.; Li, S. Enhanced electronic transport in Fe $\mathrm{F}^{3+}$-doped $\mathrm{TiO}_{2}$ for high efficiency perovskite solar cells. J. Mater. Chem. C 2017, 5, 10754-10760. [CrossRef]

74. Seo, J.Y.; Uchida, R.; Kim, H.S.; Saygili, Y.; Luo, J.; Moore, C.; Kerrod, J.; Wagstaff, A.; Eklund, M.; McIntyre, R.; et al. Boosting the Efficiency of Perovskite Solar Cells with CsBr-Modified Mesoporous $\mathrm{TiO}_{2}$ Beads as Electron-Selective Contact. Adv. Funct. Mater. 2017, 28, 1705763. [CrossRef]

75. Li, W.; Zhang, W.; Van Reenen, S.; Sutton, R.J.; Fan, J.; Haghighirad, A.; Johnston, M.; Wang, L.; Snaith, H. Enhanced UV-Light Stability of Planar Heterojunction Perovskite Solar Cells with Caesium Bromide Interface Modification. Energy Environ. Sci. 2016, 9, 490-498. [CrossRef]

76. Sun, Y.; Fang, X.; Ma, Z.; Xu, L.; Lu, Y.; Yu, Q.; Yuan, N.; Ding, J. Enhanced UV-Light Stability of Organometal Halide Perovskite Solar Cells with Interface Modification and a UV Absorption Layer. J. Mater. Chem. C 2017, 5, 8682-8687. [CrossRef]

77. Tan, H.; Jain, A.; Voznyy, O.; Lan, X.; de Arquer, F.P.G.; Fan, J.Z.; Quintero-Bermudez, R.; Yuan, M.; Zhang, B.; Zhao, Y.; et al. Efficient and stable solution-processed planar perovskite solar cells via contact passivation. Science 2017, 355, 722-726. [CrossRef] [PubMed]

78. Li, H.; Shi, W.; Huang, W.; Yao, E.-P.; Han, J.; Chen, Z.; Yang, Y. Carbon Quantum Dots/TiOx Electron Transport Layer Boosts Efficiency of Planar Heterojunction Perovskite Solar Cells to 19\%. Nano Lett. 2017, 17, 2328-2335. [CrossRef] [PubMed]

79. Peng, J.; Wu, Y.; Ye, W.; Jacobs, D.A.; Shen, H.; Fu, X.; Wan, Y.; Duong, T.; Wu, N.; Barugkin, C.; et al. Interface Passivation Using Ultrathin Polymer-Fullerene Films for High-Efficiency Perovskite Solar Cells with Negligible Hysteresis. Energy Environ. Sci. 2017, 10, 1792-1800. [CrossRef]

80. Habisreutinger, S.N.; Noel, N.K.; Snaith, H.J.; Nicholas, R.J. Investigating the Role of 4-Tert Butylpyridine in Perovskite Solar Cells. Adv. Energy Mater. 2017, 7, 1-8. [CrossRef]

81. Choi, J.; Song, S.; Hörantner, M.T.; Snaith, H.J.; Park, T. Well-Defined Nanostructured, Single-Crystalline $\mathrm{TiO}_{2}$ Electron Transport Layer for Efficient Planar Perovskite Solar Cells. ACS Nano 2016, 10, 6029-6036. [CrossRef] [PubMed]

82. Tiwana, P.; Docampo, P.; Johnston, M.B.; Snaith, H.J.; Herz, L.M. Electron Mobility and Injection Dynamics in Mesoporous $\mathrm{ZnO}, \mathrm{SnO}_{2}$, and $\mathrm{TiO}_{2}$ Films Used in Dye-Sensitized Solar Cells. ACS Nano 2011, 5, 5158-5166. [CrossRef] [PubMed]

83. Jiang, Q.; Zhang, L.; Wang, H.; Yang, X.; Meng, J.; Liu, H.; Yin, Z.; Wu, J.; Zhang, X.; You, J.; et al. Enhanced Electron Extraction Using $\mathrm{SnO}_{2}$ for High-Efficiency Planar-Structure $\mathrm{HC}\left(\mathrm{NH}_{2}\right)_{2} \mathrm{PbI}_{3}$-Based Perovskite Solar Cells. Nat. Energy 2016, 1, 16177. [CrossRef]

84. Zhu, Z.; Bai, Y.; Liu, X.; Chueh, C.-C.; Yang, S.; Jen, A.K.-Y. Enhanced Efficiency and Stability of Inverted Perovskite Solar Cells Using Highly Crystalline $\mathrm{SnO}_{2}$ Nanocrystals as the Robust Electron-Transporting Layer. Adv. Mater. 2016, 28, 6478-6484. [CrossRef] [PubMed]

85. Zhu, Z.; Zhao, D.; Chueh, C.-C.; Shi, X.; Li, Z.; Jen, A.K.-Y. Highly Efficient and Stable Perovskite Solar Cells Enabled by All-Crosslinked Charge-Transporting Layers. Joule 2018, 2, 168-183. [CrossRef]

86. Mejía Escobar, M.A.; Pathak, S.; Liu, J.; Snaith, H.J.; Jaramillo, F. $\mathrm{ZrO}_{2} / \mathrm{TiO}_{2}$ Electron Collection Layer for Efficient Meso-Superstructured Hybrid Perovskite Solar Cells. ACS Appl. Mater. Interfaces 2017, 9, 2342-2349. [CrossRef] [PubMed]

87. Malinkiewicz, O.; Yella, A.; Lee, Y.H.; Espallargas, G.M.; Graetzel, M.; Nazeeruddin, M.K.; Bolink, H.J. Perovskite Solar Cells Employing Organic Charge-Transport Layers. Nat. Photon. 2013, 8, 128-132. [CrossRef]

88. Gong, J.; Darling, S.B.; You, F. Perovskite Photovoltaics: Life-Cycle Assessment of Energy and Environmental Impacts. Energy Environ. Sci. 2015, 8, 1953-1968. [CrossRef]

89. Wang, J.T.-W.; Ball, J.M.; Barea, E.M.; Abate, A.; Alexander-Webber, J.A.; Huang, J.; Saliba, M.; Mora-Sero, I.; Bisquert, J.; Snaith, H.J.; et al. Low-Temperature Processed Electron Collection Layers of Graphene/ $/ \mathrm{TiO}_{2}$ Nanocomposites in Thin Film Perovskite Solar Cells. Nano Lett. 2014, 14, 724-730. [CrossRef] [PubMed]

90. Dualeh, A.; Moehl, T.; Tétreault, N.; Teuscher, J.; Gao, P.; Nazeeruddin, M.K.; Grätzel, M. Impedance Spectroscopic Analysis of Lead Iodide Perovskite-Sensitized Solid-State Solar Cells. ACS Nano 2014, 8, 362-373. [CrossRef] [PubMed] 
91. Snaith, H.J.; Abate, A.; Ball, J.M.; Eperon, G.E.; Leijtens, T.; Noel, N.K.; Stranks, S.D.; Wang, J.T.-W.; Wojciechowski, K.; Zhang, W. Anomalous Hysteresis in Perovskite Solar Cells. J. Phys. Chem. Lett. 2014, 5, 1511-1515. [CrossRef] [PubMed]

92. Chen, B.; Yang, M.; Priya, S.; Zhu, K. Origin of J-V Hysteresis in Perovskite Solar Cells. J. Phys. Chem. Lett. 2016, 7, 905-917. [CrossRef] [PubMed]

93. Sanchez, R.S.; Gonzalez-Pedro, V.; Lee, J.W.; Park, N.G.; Kang, Y.S.; Mora-Sero, I.; Bisquert, J. Slow Dynamic Processes in Lead Halide Perovskite Solar Cells. Characteristic Times and Hysteresis. J. Phys. Chem. Lett. 2014, 5, 2357-2363. [CrossRef] [PubMed]

94. Wu, Y.; Shen, H.; Walter, D.; Jacobs, D.; Duong, T.; Peng, J.; Jiang, L.; Cheng, Y.B.; Weber, K. On the Origin of Hysteresis in Perovskite Solar Cells. Adv. Funct. Mater. 2016, 26, 6807-6813. [CrossRef]

95. Shao, Y.; Xiao, Z.; Bi, C.; Yuan, Y.; Huang, J. Origin and Elimination of Photocurrent Hysteresis by Fullerene Passivation in $\mathrm{CH}_{3} \mathrm{NH}_{3} \mathrm{PbI}_{3}$ Planar Heterojunction Solar Cells. Nat. Commun. 2014, 5, 1-7. [CrossRef] [PubMed]

96. Ono, L.K.; Qi, Y. Surface and Interface Aspects of Organometal Halide Perovskite Materials and Solar Cells. J. Phys. Chem. Lett. 2016, 7, 4764-4794. [CrossRef] [PubMed]

97. Ergen, O.; Gilbert, S.M.; Pham, T.; Turner, S.J.; Tan, M.T.Z.; Worsley, M.A.; Zettl, A. Graded Bandgap Perovskite Solar Cells. Nat Mater 2017, 16, 522-525. [CrossRef] [PubMed]

98. Bahtiar, A.; Rahmanita, S.; Inayatie, Y.D. Pin-Hole Free Perovskite Film for Solar Cells Application Prepared by Controlled Two-Step Spin-Coating Method. IOP Conf. Ser. Mater. Sci. Eng. 2017, 196, 012037. [CrossRef]

99. Han, F.; Luo, J.; Wan, Z.; Liu, X.; Jia, C. Dissolution-Recrystallization Method for High Efficiency Perovskite Solar Cells. Appl. Surf. Sci. 2017, 408, 34-37. [CrossRef]

100. Li, Z.; Yang, M.; Park, J.-S.; Wei, S.H.; Berry, J.J.; Zhu, K. Stabilizing Perovskite Structures by Tuning Tolerance Factor: Formation of Formamidinium and Cesium Lead Iodide Solid-State Alloys. Chem. Mater. 2016, 28, 284-292. [CrossRef]

101. Yi, C.; Luo, J.; Meloni, S.; Boziki, A.; Ashari-Astani, N.; Gratzel, C.; Zakeeruddin, S.M.; Rothlisberger, U.; Gratzel, M. Entropic Stabilization of Mixed A-Cation $\mathrm{ABX}_{3}$ Metal Halide Perovskites for High Performance Perovskite Solar Cells. Energy Environ. Sci. 2016, 9, 656-662. [CrossRef]

102. Yao, E.P.; Sun, P.; Huang, W.; Yao, E.P.; Yang, Y.; Wang, M. Efficient Planar Perovskite Solar Cells Using Halide Sr-Substituted Pb Perovskite. Nano Energy 2017, 36, 213-222.

103. Eperon, G.E.; Beck, C.E.; Snaith, H.J. Cation Exchange for Thin Film Lead Iodide Perovskite Interconversion. Mater. Horiz. 2016, 3, 63-71. [CrossRef]

104. Meng, L.; You, J.; Guo, T.-F.F.; Yang, Y. Recent Advances in the Inverted Planar Structure of Perovskite Solar Cells. Acc. Chem. Res. 2015, 49, 155-165. [CrossRef] [PubMed]

105. Heo, J.H.; Han, H.J.; Kim, D.; Ahn, T.K.; Im, S.H. Hysteresis-Less Inverted $\mathrm{CH}_{3} \mathrm{NH}_{3} \mathrm{PbI}_{3}$ Planar Perovskite Hybrid Solar Cells with 18.1\% Power Conversion Efficiency. Energy Environ. Sci. 2015, 8, 1602-1608. [CrossRef]

106. Wu, Y.; Yang, X.; Chen, W.; Yue, Y.; Cai, M.; Xie, F.; Bi, E.; Islam, A.; Han, L. Perovskite Solar Cells with 18.21\% Efficiency and Area over $1 \mathrm{Cm}^{2}$ Fabricated by Heterojunction Engineering. Nat. Energy 2016, 1, 16148. [CrossRef]

107. Chiang, C.-H.; Wu, C.-G. Bulk Heterojunction Perovskite-PCBM Solar Cells with High Fill Factor. Nat. Photon. 2016, 10, 196. [CrossRef]

108. Bailie, C.D.; McGehee, M.D. High-Efficiency Tandem Perovskite Solar Cells. MRS Bull. 2015, 40, 681-686. [CrossRef]

109. De Vos, A. Detailed Balance Limit of the Efficiency of Tandem Solar Cells. J. Phys. D Appl. Phys. 1980, 13, 839. [CrossRef]

110. Futscher, M.H.; Ehrler, B. Efficiency Limit of Perovskite/Si Tandem Solar Cells. ACS Energy Lett. 2016, 2-7. [CrossRef]

111. Uzu, H.; Ichikawa, M.; Hino, M.; Nakano, K.; Meguro, T.; Hernández, J.L.; Kim, H.-S.; Park, N.-G.; Yamamoto, K. High Efficiency Solar Cells Combining a Perovskite and a Silicon Heterojunction Solar Cells via an Optical Splitting System. Appl. Phys. Lett. 2015, 106, 13506. [CrossRef]

112. Todorov, T.; Gershon, T.; Gunawan, O.; Sturdevant, C.; Guha, S. Perovskite-Kesterite Monolithic Tandem Solar Cells with High Open-Circuit Voltage. Appl. Phys. Lett. 2014, 105, 173902. [CrossRef] 
113. Loper, P.; Moon, S.-J.; Martin de Nicolas, S.; Niesen, B.; Ledinsky, M.; Nicolay, S.; Bailat, J.; Yum, J.-H.; De Wolf, S.; Ballif, C. Organic-Inorganic Halide Perovskite/Crystalline Silicon Four-Terminal Tandem Solar Cells. Phys. Chem. Chem. Phys. 2015, 17, 1619-1629. [CrossRef] [PubMed]

114. Lang, F.; Gluba, M.A.; Albrecht, S.; Rappich, J.; Korte, L.; Rech, B.; Nickel, N.H. Perovskite Solar Cells with Large-Area CVD-Graphene for Tandem Solar Cells. J. Phys. Chem. Lett. 2015, 6, 2745-2750. [CrossRef] [PubMed]

115. Mailoa, J.P.; Bailie, C.D.; Johlin, E.C.; Hoke, E.T.; Akey, A.J.; Nguyen, W.H.; McGehee, M.D.; Buonassisi, T. A 2-Terminal Perovskite/Silicon Multijunction Solar Cell Enabled by a Silicon Tunnel Junction. Appl. Phys. Lett. 2015, 106. [CrossRef]

116. Werner, J.; Dubuis, G.; Walter, A.; Löper, P.; Moon, S.-J.; Nicolay, S.; Morales-Masis, M.; De Wolf, S.; Niesen, B.; Ballif, C. Sputtered Rear Electrode with Broadband Transparency for Perovskite Solar Cells. Sol. Energy Mater. Sol. Cells 2015, 141, 407-413. [CrossRef]

117. Kranz, L.; Abate, A.; Feurer, T.; Fu, F.; Avancini, E.; Löckinger, J.; Reinhard, P.; Zakeeruddin, S.M.; Grätzel, M.; Buecheler, S.; et al. High-Efficiency Polycrystalline Thin Film Tandem Solar Cells. J. Phys. Chem. Lett. 2015, 6, 2676-2681. [CrossRef] [PubMed]

118. Zhao, D.; Yu, Y.; Wang, C.; Liao, W.; Shrestha, N.; Grice, C.R.; Cimaroli, A.J.; Guan, L.; Ellingson, R.J.; Zhu, K.; et al. Low-Bandgap Mixed Tin-lead Iodide Perovskite Absorbers with Long Carrier Lifetimes for All-Perovskite Tandem Solar Cells. Nat. Energy 2017, 2, 17018. [CrossRef]

119. Li, G.; Chang, W.-H.; Yang, Y. Low-Bandgap Conjugated Polymers Enabling Solution-Processable Tandem Solar Cells. Nat. Rev. Mat. 2017, 2, 17043. [CrossRef]

120. Fu, F.; Feurer, T.; Jäger, T.; Avancini, E.; Bissig, B.; Yoon, S.; Buecheler, S.; Tiwari, A.N. Low-Temperature-Processed Efficient Semi-Transparent Planar Perovskite Solar Cells for Bifacial and Tandem Applications. Nat. Commun. 2015, 6, 8932. [CrossRef] [PubMed]

121. McMeekin, D.P.; Sadoughi, G.; Rehman, W.; Eperon, G.E.; Saliba, M.; Hörantner, M.T.; Haghighirad, A.; Sakai, N.; Korte, L.; Rech, B.; et al. A Mixed-Cation Lead Mixed-Halide Perovskite Absorber for Tandem Solar Cells. Science 2016, 351, 151-155. [CrossRef] [PubMed]

122. Leguy, A.M.A.; Hu, Y.; Campoy-Quiles, M.; Alonso, M.I.; Weber, O.J.; Azarhoosh, P.; Van Schilfgaarde, M.; Weller, M.T.; Bein, T.; Nelson, J.; et al. Reversible Hydration of $\mathrm{CH}_{3} \mathrm{NH}_{3} \mathrm{PbI}_{3}$ in Films, Single Crystals, and Solar Cells. Chem. Mater. 2015, 27, 3397-3407. [CrossRef]

123. Niu, G.; Guo, X.; Wang, L. Review of Recent Progress in Chemical Stability of Perovskite Solar Cells. J. Mater. Chem. A 2015, 3, 8970-8980. [CrossRef]

124. Frost, J.M.; Butler, K.T.; Brivio, F.; Hendon, C.H.; van Schilfgaarde, M.; Walsh, A. Atomistic Origins of High-Performance in Hybrid Halide Perovskite Solar Cells. Nano Lett. 2014, 14, 2584-2590. [CrossRef] [PubMed]

125. Yang, J.; Siempelkamp, B.D.; Liu, D.; Kelly, T.L. Investigation of $\mathrm{CH}_{3} \mathrm{NH}_{3} \mathrm{PbI}_{3}$ Degradation Rates and Mechanisms in Controlled Humidity Environments Using in Situ Techniques. ACS Nano 2015, 9, 1955-1963. [CrossRef] [PubMed]

126. Leijtens, T.; Eperon, G.E.; Pathak, S.; Abate, A.; Lee, M.M.; Snaith, H.J. Overcoming Ultraviolet Light Instability of Sensitized $\mathrm{TiO}_{2}$ with Meso-Superstructured Organometal Tri-Halide Perovskite Solar Cells. Nat. Commun. 2013, 4, 2885. [CrossRef] [PubMed]

127. Philippe, B.; Park, B.-W.; Lindblad, R.; Oscarsson, J.; Ahmadi, S.; Johansson, E.M.J.; Rensmo, H. Chemical and Electronic Structure Characterization of Lead Halide Perovskites and Stability Behavior under Different Exposures-A Photoelectron Spectroscopy Investigation. Chem. Mater. 2015, 27, 1720-1731. [CrossRef]

128. Conings, B.; Drijkoningen, J.; Gauquelin, N.; Babayigit, A.; D’Haen, J.; D'Olieslaeger, L.; Ethirajan, A.; Verbeeck, J.; Manca, J.; Mosconi, E.; et al. Intrinsic Thermal Instability of Methylammonium Lead Trihalide Perovskite. Adv. Energy Mater. 2015, 5, 1500477. [CrossRef]

129. Kim, N.-K.; Min, Y.H.; Noh, S.; Cho, E.; Jeong, G.; Joo, M.; Ahn, S.-W.; Lee, J.S.; Kim, S.; Ihm, K.; et al. Investigation of Thermally Induced Degradation in $\mathrm{CH}_{3} \mathrm{NH}_{3} \mathrm{PbI}_{3}$ Perovskite Solar Cells Using In-Situ Synchrotron Radiation Analysis. Sci. Rep. 2017, 7, 4645. [CrossRef] [PubMed]

130. Grancini, G.; Roldán-Carmona, C.; Zimmermann, I.; Mosconi, E.; Lee, X.; Martineau, D.; Narbey, S.; Oswald, F.; De Angelis, F.; Graetzel, M.; et al. One-Year Stable Perovskite Solar Cells by 2D/3D Interface Engineering. Nat. Commun. 2017, 8, 15684. [CrossRef] [PubMed] 
131. Noh, J.H.; Im, S.H.; Heo, J.H.; Mandal, T.N.; Seok, S.I. Chemical Management for Colorful, Efficient, and Stable Inorganic-Organic Hybrid Nanostructured Solar Cells. Nano Lett. 2013, 13, 1764-1769. [CrossRef] [PubMed]

132. Jeon, N.J.; Noh, J.H.; Kim, Y.C.; Yang, W.S.; Ryu, S.; Seok, S.I. Solvent Engineering for High-Performance Inorganic-Organic Hybrid Perovskite Solar Cells. Nat. Mater. 2014, 13, 897-903. [CrossRef] [PubMed]

133. Hoke, E.T.; Slotcavage, D.J.; Dohner, E.R.; Bowring, A.R.; Karunadasa, H.I.; McGehee, M.D. Reversible Photo-Induced Trap Formation in Mixed-Halide Hybrid Perovskites for Photovoltaics. Chem. Sci. 2015, 6, 613-617. [CrossRef] [PubMed]

134. Jiang, Q.; Rebollar, D.; Gong, J.; Piacentino, E.L.; Zheng, C.; Xu, T. Pseudohalide-Induced Moisture Tolerance in Perovskite $\mathrm{CH}_{3} \mathrm{NH}_{3} \mathrm{~Pb}(\mathrm{SCN})_{2}$ I Thin Films. Angew. Chem.-Int. Ed. 2015, 54, 7617-7620. [CrossRef] [PubMed]

135. Chen, Y.; Li, B.; Huang, W.; Gao, D.; Liang, Z. Efficient and Reproducible $\mathrm{CH}_{3} \mathrm{NH}_{3} \mathrm{PbI}_{3-\mathrm{x}}(\mathrm{SCN})_{\mathrm{x}}$ Perovskite Based Planar Solar Cells. Chem. Commun. 2015, 51, 11997-11999. [CrossRef] [PubMed]

136. Ganose, A.M.; Savory, C.N.; Scanlon, D.O. (CH3NH3)2Pb(SCN)2I2: A More Stable Structural Motif for Hybrid Halide Photovoltaics? J. Phys. Chem. Lett. 2015, 6, 4594-4598. [CrossRef] [PubMed]

137. Tai, Q.; You, P.; Sang, H.; Liu, Z.; Hu, C.; Chan, H.L.W.; Yan, F. Efficient and Stable Perovskite Solar Cells Prepared in Ambient Air Irrespective of the Humidity. Nat. Commun. 2016, 7, 11105. [CrossRef] [PubMed]

138. Eperon, G.E.; Stranks, S.D.; Menelaou, C.; Johnston, M.B.; Herz, L.M.; Snaith, H.J. Formamidinium Lead Trihalide: A Broadly Tunable Perovskite for Efficient Planar Heterojunction Solar Cells. Energy Environ. Sci. 2014, 7, 982-988. [CrossRef]

139. Koh, T.M.; Fu, K.; Fang, Y.; Chen, S.; Sum, T.C.; Mathews, N. Formamidinium-Containing Metal-Halide: An Alternative Material for Near-IR Absorption Perovskite Solar Cells. J. Phys. Chem. C 2013, 118, 16458-16462. [CrossRef]

140. Qin, X.; Zhao, Z.; Wang, Y.; Wu, J.; Jiang, Q.; You, J. Recent Progress in Stability of Perovskite Solar Cells. J. Semicond. 2017, 38, 11002. [CrossRef]

141. Choi, H.; Jeong, J.; Kim, H.-B.; Kim, S.; Walker, B.; Kim, G.-H.; Kim, J.Y. Cesium-Doped Methylammonium Lead Iodide Perovskite Light Absorber for Hybrid Solar Cells. Nano Energy 2014, 7, 80-85. [CrossRef]

142. Jeon, N.J.; Noh, J.H.; Yang, W.S.; Kim, Y.C.; Ryu, S.; Seo, J.; Seok, S.I. Compositional Engineering of Perovskite Materials for High-Performance Solar Cells. Nature 2015, 517, 476-480. [CrossRef] [PubMed]

143. Yang, W.S.; Noh, J.H.; Jeon, N.J.; Kim, Y.C.; Ryu, S.; Seo, J.; Seok, S.I. High-Performance Photovoltaic Perovskite Layers Fabricated through Intramolecular Exchange. Science 2015, 348, 1234-1237. [CrossRef] [PubMed]

144. Wang, Q.; Zheng, X.; Deng, Y.; Zhao, J.; Chen, Z.; Huang, J. Stabilizing the $\alpha$-Phase of $\mathrm{CsPbI}_{3}$ Perovskite by Sulfobetaine Zwitterions in One-Step Spin-Coating Films. Joule 2017, 1, 371-382. [CrossRef]

145. Eperon, G.E.; Paterno, G.M.; Sutton, R.J.; Zampetti, A.; Haghighirad, A.A.; Cacialli, F.; Snaith, H.J. Inorganic Caesium Lead Iodide Perovskite Solar Cells. J. Mater. Chem. A 2015, 3, 19688-19695. [CrossRef]

146. Saliba, M.; Matsui, T.; Seo, J.-Y.; Domanski, K.; Correa-Baena, J.-P.; Nazeeruddin, M.K.; Zakeeruddin, S.M.; Tress, W.; Abate, A.; Hagfeldt, A.; et al. Cesium-Containing Triple Cation Perovskite Solar Cells: Improved Stability, Reproducibility and High Efficiency. Energy Environ. Sci. 2016, 9, 1989-1997. [CrossRef] [PubMed]

147. Sun, Y.; Peng, J.; Chen, Y.; Yao, Y.; Liang, Z. Triple-Cation Mixed-Halide Perovskites: Towards Efficient, Annealing-Free and Air-Stable Solar Cells Enabled by $\mathrm{Pb}(\mathrm{SCN})_{2}$ Additive. Sci. Rep. 2017, 7, 1-7. [CrossRef] [PubMed]

148. Bu, T.; Liu, X.; Zhou, Y.; Yi, J.; Huang, X.; Luo, L.; Xiao, J.; Ku, Z.; Peng, Y.; Huang, F.; et al. Novel Quadruple-Cation Absorber for Universal Hysteresis Elimination for High Efficiency and Stable Perovskite Solar Cells. Energy Environ. Sci. 2017, 10, 2509-2515. [CrossRef]

149. Hu, Y.; Bai, F.; Liu, X.; Ji, Q.; Miao, X.; Qiu, T.; Zhang, S. Bismuth Incorporation Stabilized $\alpha$-CsPbI 3 for Fully Inorganic Perovskite Solar Cells. ACS Energy Lett. 2017, 2, 2219-2227. [CrossRef]

150. Zhang, X.; Ren, X.; Liu, B.; Munir, R.; Zhu, X.; Yang, D.; Li, J.; Liu, Y.; Smilgies, D.-M.; Li, R.; et al. Stable High Efficiency Two-Dimensional Perovskite Solar Cells via Cesium Doping. Energy Environ. Sci. 2017, 10, 2095-2102. [CrossRef]

151. Wang, Z.; Lin, Q.; Chmiel, F.P.; Sakai, N.; Herz, L.M.; Snaith, H.J. Efficient Ambient-Air-Stable Solar Cells with 2D-3D Heterostructured Butylammonium-Caesium-Formamidinium Lead Halide Perovskites. Nat. Energy 2017, 2, 1-10. [CrossRef] 
152. Batmunkh, M.; Shearer, C.J.; Bat-Erdene, M.; Biggs, M.J.; Shapter, J.G. Single-Walled Carbon Nanotubes Enhance the Efficiency and Stability of Mesoscopic Perovskite Solar Cells. ACS Appl. Mater. Interfaces 2017, 9 , 19945-19954. [CrossRef] [PubMed]

153. Roose, B.; Pathak, S.K.; Steiner, U. Doping of $\mathrm{TiO}_{2}$ for sensitised solar cells. Chem. Soc. Rev. 2015, 44, 8326-8349. [CrossRef] [PubMed]

154. Yang, J.; Siempelkamp, B.D.; Mosconi, E.; De Angelis, F.; Kelly, T.L. Origin of the Thermal Instability in $\mathrm{CH}_{3} \mathrm{NH}_{3} \mathrm{PbI}_{3}$ Thin Films Deposited on ZnO. Chem. Mater. 2015, 27, 4229-4236. [CrossRef]

155. Arafat Mahmud, M.; Kumar Elumalai, N.; Baishakhi Upama, M.; Wang, D.; Gonçales, V.R.; Wright, M.; Justin Gooding, J.; Haque, F.; Xu, C.; Uddin, A. Cesium Compounds as Interface Modifiers for Stable and Efficient Perovskite Solar Cells. Sol. Energy Mater. Sol. Cells 2018, 174, 172-186. [CrossRef]

156. Cao, J.; Wu, B.; Chen, R.; Wu, Y.; Hui, Y.; Mao, B.W.; Zheng, N. Efficient, Hysteresis-Free, and Stable Perovskite Solar Cells with ZnO as Electron-Transport Layer: Effect of Surface Passivation. Adv. Mater. 2018, 1705596, 1-9. [CrossRef] [PubMed]

157. Mahmud, M.A.; Elumalai, N.K.; Upama, M.B.; Wang, D.; Zarei, L.; Gonçales, V.R.; Wright, M.; Xu, C.; Haque, F.; Uddin, A. Adsorbed Carbon Nanomaterials for Surface and Interface-Engineered Stable Rubidium Multi-Cation Perovskite Solar Cells. Nanoscale 2017, 773-790. [CrossRef] [PubMed]

158. Pang, A.; Shen, D.; Wei, M.; Chen, Z.-N. Highly Efficient Perovskite Solar Cells Based on $\mathrm{Zn}_{2} \mathrm{Ti}_{3} \mathrm{O}_{8}$ Nanoparticles as Electron Transport Material. ChemSusChem 2017, 11, 424-431. [CrossRef] [PubMed]

159. Wang, X.; Deng, L.-L.; Wang, L.-Y.; Dai, S.-M.; Xing, Z.; Zhan, X.-X.; Lu, X.-Z.; Xie, S.-Y.; Huang, R.-B.; Zheng, L.-S. Cerium Oxide Standing out as an Electron Transport Layer for Efficient and Stable Perovskite Solar Cells Processed at Low Temperature. J. Mater. Chem. A 2017, 5, 1706-1712. [CrossRef]

160. Shin, S.S.; Yeom, E.J.; Yang, W.S.; Hur, S.; Kim, M.G.; Im, J.; Seo, J.; Noh, J.H.; Seok, S.I. Colloidally Prepared La-Doped $\mathrm{BaSnO}_{3}$ Electrodes for Efficient, Photostable Perovskite Solar Cells. Science 2017, 356, 167-171. [CrossRef] [PubMed]

161. Lee, K.; Ryu, J.; Yu, H.; Yun, J.; Lee, J.; Jang, J. Enhanced Efficiency and Air-Stability of NiOX-Based Perovskite Solar Cells via PCBM Electron Transport Layer Modification with Triton X-100. Nanoscale 2017, 9, 16249-16255. [CrossRef] [PubMed]

162. Kim, G.-H.; Jang, H.; Yoon, Y.J.; Jeong, J.; Park, S.Y.; Walker, B.; Jeon, I.-Y.; Jo, Y.; Yoon, H.; Kim, M.; et al. Fluorine Functionalized Graphene Nano Platelets for Highly Stable Inverted Perovskite Solar Cells. Nano Lett. 2017, 17, 6385-6390. [CrossRef] [PubMed]

163. Kim, H.I.; Kim, M.-J.; Choi, K.; Lim, C.; Kim, Y.-H.; Kwon, S.-K.; Park, T. Improving the Performance and Stability of Inverted Planar Flexible Perovskite Solar Cells Employing a Novel NDI-Based Polymer as the Electron Transport Layer. Adv. Energy Mater. 2018, 1702872. [CrossRef]

164. Mahmud, M.A.; Elumalai, N.K.; Upama, M.B.; Wang, D.; Gonçales, V.R.; Wright, M.; Xu, C.; Haque, F.; Uddin, A. A High Performance and Low-Cost Hole Transporting Layer for Efficient and Stable Perovskite Solar Cells. Phys. Chem. Chem. Phys. 2017, 19, 21033-21045. [CrossRef] [PubMed]

165. Calió, L.; Momblona, C.; Gil-Escrig, L.; Kazim, S.; Sessolo, M.; Sastre-Santos, Á.; Bolink, H.J.; Ahmad, S. Vacuum Deposited Perovskite Solar Cells Employing Dopant-Free Triazatruxene as the Hole Transport Material. Sol. Energy Mater. Sol. Cells 2017, 163, 237-241. [CrossRef]

166. Matsui, T.; Petrikyte, I.; Malinauskas, T.; Domanski, K.; Daskeviciene, M.; Steponaitis, M.; Gratia, P.; Tress, W.; Correa-Baena, J.P.; Abate, A.; et al. Additive-free transparent triarylamine-based polymeric hole-transport materials for stable perovskite solar cells. ChemSusChem 2016, 9, 2567-2571. [CrossRef] [PubMed]

167. Li, Q.; Zhao, Y.; Fu, R.; Zhou, W.; Zhao, Y.; Lin, F.; Liu, S.; Yu, D.; Zhao, Q. Enhanced Long-Term Stability of Perovskite Solar Cells Using a Double-Layer Hole Transport Material. J. Mater. Chem. A 2017, 5, 14881-14886. [CrossRef]

168. Hawash, Z.; Ono, L.K.; Raga, S.R.; Lee, M.V.; Qi, Y. Air-Exposure Induced Dopant Redistribution and Energy Level Shifts in Spin-Coated Spiro-MeOTAD Films. Chem. Mater. 2015, 27, 562-569. [CrossRef]

169. Kim, G.-W.; Kang, G.; Malekshahi Byranvand, M.; Lee, G.-Y.; Park, T. Gradated Mixed Hole Transport Layer in a Perovskite Solar Cell: Improving Moisture Stability and Efficiency. ACS Appl. Mater. Interfaces 2017, 9, 27720-27726. [CrossRef] [PubMed]

170. Ginting, R.T.; Jeon, M.-K.; Lee, K.-J.; Jin, W.-Y.; Kim, T.-W.; Kang, J.-W. Degradation Mechanism of Planar-Perovskite Solar Cells: Correlating Evolution of Iodine Distribution and Photocurrent Hysteresis. J. Mater. Chem. A 2017, 5, 4527-4534. [CrossRef] 
171. Habisreutinger, S.N.; Leijtens, T.; Eperon, G.E.; Stranks, S.D.; Nicholas, R.J.; Snaith, H.J. Carbon Nanotube/Polymer Composites as a Highly Stable Hole Collection Layer in Perovskite Solar Cells. Nano Lett. 2014, 14, 5561-5568. [CrossRef] [PubMed]

172. Luo, Q.; Ma, H.; Zhang, Y.; Yin, X.; Yao, Z.; Wang, N.; Li, J.; Fan, S.; Jiang, K.; Lin, H. Cross-Stacked Superaligned Carbon Nanotube Electrodes for Efficient Hole Conductor-Free Perovskite Solar Cells. J. Mater. Chem. A 2016, 4, 5569-5577. [CrossRef]

173. Mei, A.; Li, X.; Liu, L.; Ku, Z.; Liu, T.; Rong, Y.; Xu, M.; Hu, M.; Chen, J.; Yang, Y.; et al. A Hole-Conductor-Free, Fully Printable Mesoscopic Perovskite Solar Cell with High Stability. Science 2014, 345, 295-298. [CrossRef] [PubMed]

174. Koh, C.W.; Heo, J.H.; Uddin, M.A.; Kwon, Y.-W.; Choi, D.H.; Im, S.H.; Woo, H.Y. Enhanced Efficiency and Long-Term Stability of Perovskite Solar Cells by Synergistic Effect of Nonhygroscopic Doping in Conjugated Polymer-Based Hole-Transporting Layer. ACS Appl. Mater. Interfaces 2017, 9, 43846-43854. [CrossRef] [PubMed]

175. Wang, D.; Elumalai, N.K.; Mahmud, M.A.; Wright, M.; Upama, M.B.; Chan, K.H.; Xu, C.; Haque, F.; Conibeer, G.; Uddin, A. V2O5-PEDOT: PSS Bilayer as Hole Transport Layer for Highly Efficient and Stable Perovskite Solar Cells. Org. Electron. Physics, Mater. Appl. 2018, 53, 66-73.

176. Ma, S.; Qiao, W.; Cheng, T.; Zhang, B.; Yao, J.; Alsaedi, A.; Hayat, T.; Ding, Y.; Tan, Z.; Dai, S. Optical-Electrical-Chemical Engineering of PEDOT:PSS by Incorporation of Hydrophobic Nafion for Efficient and Stable Perovskite Solar Cells. ACS Appl. Mater. Interfaces 2018, 10, 3902-3911. [CrossRef] [PubMed]

177. Yang, L.; Cai, F.; Yan, Y.; Li, J.; Liu, D.; Pearson, A.J.; Wang, T. Conjugated Small Molecule for Efficient Hole Transport in High-Performance p-i-n Type Perovskite Solar Cells. Adv. Funct. Mater. 2017, 27, 1702613. [CrossRef]

178. Lee, J.; Kang, H.; Kim, G.; Back, H.; Kim, J.; Hong, S.; Park, B.; Lee, E.; Lee, K. Achieving Large-Area Planar Perovskite Solar Cells by Introducing an Interfacial Compatibilizer. Adv. Mater. 2017, 29, 1606363. [CrossRef] [PubMed]

179. Wang, Q.; Chueh, C.C.; Zhao, T.; Cheng, J.; Eslamian, M.; Choy, W.C.H.; Jen, A.K.Y. Effects of Self-Assembled Monolayer Modification of Nickel Oxide Nanoparticles Layer on the Performance and Application of Inverted Perovskite Solar Cells. ChemSusChem 2017, 10, 3794-3803. [CrossRef] [PubMed]

180. Zhao, X.; Kim, H.-S.; Seo, J.-Y.; Park, N.-G. Effect of Selective Contacts on the Thermal Stability of Perovskite Solar Cells. ACS Appl. Mater. Interfaces 2017, 9, 7148-7153. [CrossRef] [PubMed]

181. Guarnera, S.; Abate, A.; Zhang, W.; Foster, J.M.; Richardson, G.; Petrozza, A.; Snaith, H.J. Improving the Long-Term Stability of Perovskite Solar Cells with a Porous $\mathrm{Al}_{2} \mathrm{O}_{3}$ Buffer Layer. J. Phys. Chem. Lett. 2015, 6, 432-437. [CrossRef] [PubMed]

182. Koushik, D.; Verhees, W.J.H.; Kuang, Y.; Veenstra, S.; Zhang, D.; Verheijen, M.A.; Creatore, M.; Schropp, R.E.I. High-Efficiency Humidity-Stable Planar Perovskite Solar Cells Based on Atomic Layer Architecture. Energy Environ. Sci. 2017, 10, 91-100. [CrossRef]

183. Wei, Z.; Zheng, X.; Chen, H.; Long, X.; Wang, Z.; Yang, S. A Multifunctional C + Epoxy / Ag-Paint Cathode Enables Efficient and Stable Operation of Perovskite Solar Cells in Watery Environments. J. Mater. Chem. A 2015, 3, 16430-16434. [CrossRef]

184. Chang, C.-Y.; Lee, K.-T.; Huang, W.-K.; Siao, H.-Y.; Chang, Y.-C. High-Performance, Air-Stable, Low-Temperature Processed Semitransparent Perovskite Solar Cells Enabled by Atomic Layer Deposition. Chem. Mater. 2015, 27, 5122-5130. [CrossRef]

185. Kaltenbrunner, M.; Adam, G.; Głowacki, E.D.; Drack, M.; Schwödiauer, R.; Leonat, L.; Apaydin, D.H.; Groiss, H.; Scharber, M.C.; White, M.S.; et al. Flexible High Power-per-Weight Perovskite Solar Cells with Chromium Oxide-metal Contacts for Improved Stability in Air. Nat. Mater. 2015, 14, 1032. [CrossRef] [PubMed]

186. You, J.; Meng, L.; Song, T.-B.; Guo, T.-F.; Yang, Y.M.; Chang, W.-H.; Hong, Z.; Chen, H.; Zhou, H.; Chen, Q.; et al. Improved Air Stability of Perovskite Solar Cells via Solution-Processed Metal Oxide Transport Layers. Nat. Nanotechnol. 2015, 11, 75. [CrossRef] [PubMed]

187. Hwang, I.; Jeong, I.; Lee, J.; Ko, M.J.; Yong, K. Enhancing Stability of Perovskite Solar Cells to Moisture by the Facile Hydrophobic Passivation. ACS Appl. Mater. Interfaces 2015, 7, 17330-17336. [CrossRef] [PubMed] 
188. Cheacharoen, R.; Rolston, N.J.; Harwood, D.; Bush, K.A.; Dauskardt, R.H.; McGehee, M.D. Design and Understanding of Encapsulated Perovskite Solar Cells to Withstand Temperature Cycling. Energy Environ. Sci. 2018, 11, 144-150. [CrossRef]

189. Liu, Z.; Sun, B.; Shi, T.; Tang, Z.; Liao, G. Enhanced Photovoltaic Performance and Stability of Carbon Counter Electrode Based Perovskite Solar Cells Encapsulated by PDMS. J. Mater. Chem. A 2016, 4, 10700-10709. [CrossRef]

190. Matteocci, F.; Cinà, L.; Lamanna, E.; Cacovich, S.; Divitini, G.; Midgley, P.A.; Ducati, C.; Di Carlo, A. Encapsulation for Long-Term Stability Enhancement of Perovskite Solar Cells. Nano Energy 2016, 30, 162-172. [CrossRef]

191. Han, Y.; Meyer, S.; Dkhissi, Y.; Weber, K.; Pringle, J.M.; Bach, U.; Spiccia, L.; Cheng, Y.-B. Degradation Observations of Encapsulated Planar $\mathrm{CH}_{3} \mathrm{NH}_{3} \mathrm{PbI}_{3}$ Perovskite Solar Cells at High Temperatures and Humidity. J. Mater. Chem. A 2015, 3, 8139-8147. [CrossRef]

192. Dong, Q.; Liu, F.; Wong, M.K.; Tam, H.W.; Djurišić, A.B.; Ng, A.; Surya, C.; Chan, W.K.; Ng, W.K. Encapsulation of Perovskite Solar Cells for High Humidity Conditions. ChemSusChem 2016, 9, 2597-2603. [CrossRef] [PubMed]

193. Shi, L.; Young, T.L.; Kim, J.; Sheng, Y.; Wang, L.; Chen, Y.; Feng, Z.; Keevers, M.J.; Hao, X.; Verlinden, P.J.; et al. Accelerated Lifetime Testing of Organic-Inorganic Perovskite Solar Cells Encapsulated by Polyisobutylene. ACS Appl. Mater. Interfaces 2017, 9, 25073-25081. [CrossRef] [PubMed]

194. Sanehira, E.M.; Tremolet de Villers, B.J.; Schulz, P.; Reese, M.O.; Ferrere, S.; Zhu, K.; Lin, L.Y.; Berry, J.J.; Luther, J.M. Influence of Electrode Interfaces on the Stability of Perovskite Solar Cells: Reduced Degradation Using $\mathrm{MoO}_{\mathrm{x}} / \mathrm{Al}$ for Hole Collection. ACS Energy Lett. 2016, 1, 38-45. [CrossRef]

195. Bastos, J.P.; Manghooli, S.; Jaysankar, M.; Tait, J.G.; Qiu, W.; Gehlhaar, R.; De Volder, M.; Uytterhoeven, G.; Poortmans, J.; Paetzold, U.W. Low-Cost Electrodes for Stable Perovskite Solar Cells. Appl. Phys. Lett. 2017, 110, 233902. [CrossRef]

196. Zhao, J.; Zheng, X.; Deng, Y.; Li, T.; Shao, Y.; Gruverman, A.; Shield, J.; Huang, J. Is Cu a Stable Electrode Material in Hybrid Perovskite Solar Cells for a 30-Year Lifetime? Energy Environ. Sci. 2016, 9, 3650-3656. [CrossRef]

197. Gifford, J. Dyesol Claims Perovskite Breakthrough. Available online: https://www.pv-magazine.com/ 2015/09/09/dyesol-claims-perovskite-stability-breakthrough_100021002/\#axzz31F0szmdL (accessed on 14 December 2017).

198. Crystal Clear? Available online: https:/ / www.economist.com/news/science-and-technology /21651166perovskites-may-give-silicon-solar-cells-run-their-money-crystal-clear (accessed on 14 December 2017).

199. Beets, B. LCOE for Renewables Decreases, Fossil Fuels See Increase. Available online: https://www.pvmagazine.com/2015/10/06/lcoe-for-renewables-decreases-fossil-fuels-see-increase_100021404/ (accessed on 28 December 2017).

200. Global Wind and Solar Costs to Fall Even Faster, While Coal Fades Even in China and India. Available online: https:/ / about.bnef.com/blog/global-wind-solar-costs-fall-even-faster-coal-fades-evenchina-india/ (accessed on 28 December 2017).

201. Cai, M.; Wu, Y.; Chen, H.; Yang, X.; Qiang, Y.; Han, L. Cost-Performance Analysis of Perovskite Solar Modules. Adv. Sci. 2017, 4, 1600269. [CrossRef] [PubMed]

202. Branker, K.; Pathak, M.J.M.; Pearce, J.M. A Review of Solar Photovoltaic Levelized Cost of Electricity. Renew. Sustain. Energy Rev. 2011, 15, 4470-4482. [CrossRef]

203. PV EnergyTrend. Available online: http://pv.energytrend.com/pricequotes.html (accessed on 21 November 2017).

204. Maniarasu, S.; Korukonda, T.B.; Manjunath, V.; Ramasamy, E.; Ramesh, M.; Veerappan, G. Recent Advancement in Metal Cathode and Hole-Conductor-Free Perovskite Solar Cells for Low-Cost and High Stability: A Route towards Commercialization. Renew. Sustain. Energy Rev. 2018, 82 Pt 1, 845-857. [CrossRef]

205. Petrus, M.; Music, A.; Closs, A.C.; Bijleveld, J.C.; Sirtl, M.T.; Hu, Y.; Dingemans, T.J.; Bein, T.; Docampo, P. Design Rules for the Preparation of Low-Cost Hole Transporting Materials for Perovskite Solar Cells with Moisture Barrier Properties. J. Mater. Chem. A 2017, 5, 25200-25210. [CrossRef]

206. Petrus, M.L.; Bein, T.; Dingemans, T.J.; Docampo, P. A Low Cost Azomethine-Based Hole Transporting Material for Perovskite Photovoltaics. J. Mater. Chem. A 2015, 3, 12159-12162. [CrossRef] 
207. Wu, J.; Liu, C.; Deng, X.; Zhang, L.; Hu, M.; Tang, J.; Tan, W.; Tian, Y.; Xu, B. Simple and Low-Cost Thiophene and Benzene-Conjugated Triaryamines as Hole-Transporting Materials for Perovskite Solar Cells. RSC Adv. 2017, 7, 45478-45483. [CrossRef]

208. Jeon, N.J.; Lee, J.; Noh, J.H.; Nazeeruddin, M.K.; Grätzel, M.; Seok, S.I. Efficient Inorganic-Organic Hybrid Perovskite Solar Cells Based on Pyrene Arylamine Derivatives as Hole-Transporting Materials. J. Am. Chem. Soc. 2013, 135, 19087-19090. [CrossRef] [PubMed]

209. Grisorio, R.; Roose, B.; Colella, S.; Listorti, A.; Suranna, G.P.; Abate, A. Molecular Tailoring of Phenothiazine-Based Hole-Transporting Materials for Highly Performing Perovskite Solar Cells. ACS Energy Lett. 2017, 2, 1029-1034. [CrossRef]

210. Pham, H.D.; Wu, Z.; Ono, L.K.; Manzhos, S.; Feron, K.; Motta, N.; Qi, Y.B.; Sonar, P. Low-Cost Alternative High-Performance Hole-Transport Material for Perovskite Solar Cells and Its Comparative Study with Conventional SPIRO-OMeTAD. Adv. Electron. Mater. 2017, 3, 1700139. [CrossRef]

211. Liu, X.; Kong, F.; Ghadari, R.; Jin, S.; Chen, W.; Yu, T.; Hayat, T.; Alsaedi, A.; Guo, F.; Tan, Z.; et al. Thiophene-Arylamine Hole-Transporting Materials in Perovskite Solar Cells: Substitution Position Effect. Energy Technol. 2017, 5, 1788. [CrossRef]

212. Do, K.; Choi, H.; Lim, K.; Jo, H.; Cho, J.W.; Nazeeruddin, M.K.; Ko, J. Star-Shaped Hole Transporting Materials with a Triazine Unit for Efficient Perovskite Solar Cells. Chem. Commun. 2014, 50, 10971-10974. [CrossRef] [PubMed]

213. Calió, L.; Kazim, S.; Grätzel, M.; Ahmad, S. Hole transport materials for perovskite solar cells. Angew. Chem. Int. Ed. 2016, 55, 14522. [CrossRef] [PubMed]

214. Tang, L.J.; Chen, X.; Wen, T.Y.; Yang, S.; Zhao, J.J.; Qiao, H.W.; Hou, Y.; Yang, H.G. A Solution-Processed Transparent $\mathrm{NiO}$ Hole-Extraction Layer for High-Performance Inverted Perovskite Solar Cells. Chem. Eur. J. 2018, 24, 2845. [CrossRef] [PubMed]

215. Qin, P.; Tanaka, S.; Ito, S.; Tetreault, N.; Manabe, K.; Nishino, H.; Nazeeruddin, M.K.; Grätzel, M. Inorganic Hole Conductor-Based Lead Halide Perovskite Solar Cells with $12.4 \%$ Conversion Efficiency. Nat. Commun. 2014, 5, 3834. [CrossRef] [PubMed]

216. Christians, J.A.; Fung, R.C.M.; Kamat, P.V. An Inorganic Hole Conductor for Organo-Lead Halide Perovskite Solar Cells. Improved Hole Conductivity with Copper Iodide. J. Am. Chem. Soc. 2014, 136, 758-764. [CrossRef] [PubMed]

217. Chu, L.; Liu, W.; Qin, Z.; Zhang, R.; Hu, R.; Yang, J.; Yang, J.; Li, X. Boosting Efficiency of Hole Conductor-Free Perovskite Solar Cells by Incorporating p-Type NiO Nanoparticles into Carbon Electrodes. Sol. Energy Mater. Sol. Cells 2018, 178, 164-169. [CrossRef]

218. Liu, S.; Cao, K.; Li, H.; Song, J.; Han, J.; Shen, Y.; Wang, M. Full Printable Perovskite Solar Cells Based on Mesoscopic $\mathrm{TiO}_{2} / \mathrm{Al}_{2} \mathrm{O}_{3} / \mathrm{NiO}$ (Carbon Nanotubes) Architecture. Sol. Energy 2017, 144, 158-165. [CrossRef]

219. Bhandari, K.P.; Collier, J.M.; Ellingson, R.J.; Apul, D.S. Energy Payback Time (EPBT) and Energy Return on Energy Invested (EROI) of Solar Photovoltaic Systems: A Systematic Review and Meta-Analysis. Renew. Sustain. Energy Rev. 2015, 47, 133-141. [CrossRef]

220. Celik, I.; Mason, B.E.; Phillips, A.B.; Heben, M.J.; Apul, D. Environmental Impacts from Photovoltaic Solar Cells Made with Single Walled Carbon Nanotubes. Environ. Sci. Technol. 2017, 51, 4722-4732. [CrossRef] [PubMed]

221. Espinosa, N.; Serrano-Luján, L.; Urbina, A.; Krebs, F.C. Solution and Vapour Deposited Lead Perovskite Solar Cells: Ecotoxicity from a Life Cycle Assessment Perspective. Sol. Energy Mater. Sol. Cells 2015, 137, 303-310. [CrossRef]

222. Anctil, A.; Fthenakis, V. Life Cycle Assessment of Organic Photovoltaics. Third Generation Photovoltaics Vasilis Fthenakis. IntechOpen, 2006. Available online: https://www.intechopen.com/books/thirdgeneration-photovoltaics/life-cycle-assessment-of-organic-photovoltaics (accessed on 17 September 2017).

223. Cleetus, R. Renewable Energy Surges Globally with China and India in the Lead. Available online: http:/ / blog.ucsusa.org/rachel-cleetus/renewable-energy-china-india (accessed on 28 December 2017 ).

224. Arora, B. Rising Chinese Solar Prices May Put Indian Projects at Risk. Available online: https: / /www.bloombergquint.com/business/2017/08/20/rising-chinese-solar-panel-prices-mayput-projects-bid-at-record-low-tariff-at-risk (accessed on 28 December 2017).

225. India Solar Report. Bridge to India, 2017. Available online: http:/ / www.bridgetoindia.com/reports/indiasolar-handbook-2017/ (accessed on 5 February 2018). 
226. Mahapatra, S. Renewable Energy Share Hits All-Time High in India-13.2\% of Electricity. Available online: https:/ / cleantechnica.com/2017/10/22/renewable-energy-share-hits-time-high-india-13-2-electricity / (accessed on 5 February 2018).

227. Central Statistics Office, Government of India. Energy Statistics 2017. Available online: http:/ / www.mospi.nic. in/sites/default/files/publication_reports/Energy_Statistics_2017r.pdf.pdf (accessed on 5 February 2018).

228. Central Electricity Authority, Ministry of Power, Government of India. Growth of Electricity Sector in India from 1947-2017. Available online: http:/ / www.cea.nic.in/reports/others/planning/pdm/growth_2017.pdf (accessed on 5 February 2018).

2018 by the authors. Licensee MDPI, Basel, Switzerland. This article is an open access article distributed under the terms and conditions of the Creative Commons Attribution (CC BY) license (http://creativecommons.org/licenses/by/4.0/). 